\title{
Spatiotemporal Patterns and Phenology of Tropical Vegetation Solar-Induced Chlorophyll Fluorescence across Brazilian Biomes Using Satellite Observations
}

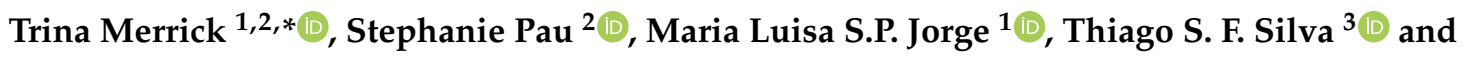 \\ Ralf Bennartz ${ }^{1,4}$ \\ 1 Department of Earth and Environmental Science, Vanderbilt University, Nashville, TN 37240, USA \\ 2 Department of Geography, 113 Collegiate Loop, Florida State University, Tallahassee, FL 32306-2190, USA \\ 3 Biological and Environmental Sciences, University of Stirling, Stirling FK9 4LA, UK \\ 4 Space Science and Engineering Center, University of Wisconsin-Madison, 1225 W. Dayton St., Madison, \\ WI 53706, USA \\ * Correspondence: trina.l.merrick@vanderbilt.edu; Tel.: +1-850-644-1706
}

Received: 19 May 2019; Accepted: 20 July 2019; Published: 24 July 2019

\begin{abstract}
Solar-induced fluorescence (SIF) has been empirically linked to gross primary productivity (GPP) in multiple ecosystems and is thus a promising tool to address the current uncertainties in carbon fluxes at ecosystem to continental scales. However, studies utilizing satellite-measured SIF in South America have concentrated on the Amazonian tropical forest, while SIF in other regions and vegetation classes remain uninvestigated. We examined three years of Orbiting Carbon Observatory-2 (OCO-2) SIF data for vegetation classes within and across the six Brazilian biomes (Amazon, Atlantic Forest, Caatinga, Cerrado, Pampa, and Pantanal) to answer the following: (1) how does satellite-measured SIF differ? (2) What is the relationship (strength and direction) of satellite-measured SIF with canopy temperature $\left(\mathrm{T}_{\mathrm{can}}\right)$, air temperature $\left(\mathrm{T}_{\text {air }}\right)$, and vapor pressure deficit $(\mathrm{VPD})$ ? (3) How does the phenology of satellite-measured SIF (duration and amplitude of seasonal integrated SIF) compare? Our analysis shows that OCO-2 captures a significantly higher mean SIF with lower variability in the Amazon and lower mean SIF with higher variability in the Caatinga compared to other biomes. OCO-2 also distinguishes the mean SIF of vegetation types within biomes, showing that evergreen broadleaf (EBF) mean SIF is significantly higher than other vegetation classes (deciduous broadleaf (DBF), grassland (GRA), savannas (SAV), and woody savannas (WSAV)) in all biomes. We show that the strengths and directions of correlations of OCO-2 mean SIF to $\mathrm{T}_{\text {can }}, \mathrm{T}_{\text {air }}$, and VPD largely cluster by biome: negative in the Caatinga and Cerrado, positive in the Pampa, and no correlations were found in the Pantanal, while results were mixed for the Amazon and Atlantic Forest. We found mean SIF most strongly correlated with VPD in most vegetation classes in most biomes,

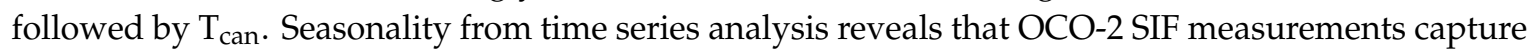
important differences in the seasonal timing of SIF for different classes, details masked when only examining mean SIF differences. We found that OCO-2 captured the highest base integrated SIF and lowest seasonal pulse integrated SIF in the Amazon for all vegetation classes, indicating continuous photosynthetic activity in the Amazon exceeds other biomes, but with small seasonal increases. Surprisingly, Pantanal EBF SIF had the highest total integrated SIF of all classes in all biomes due to a large seasonal pulse. Additionally, the length of seasons only accounts for about $30 \%$ of variability in total integrated SIF; thus, integrated SIF is likely captures differences in photosynthetic activity separate from structural differences. Our results show that satellite measurements of SIF can distinguish important functioning and phenological differences in vegetation classes and thus has the potential to improve our understanding of productivity and seasonality in the tropics.
\end{abstract}


Keywords: satellite remote sensing; tropical vegetation function; seasonality; tropical forest; time-series analysis; vapor pressure deficit; canopy temperature; tropical savanna; tropical grasslands

\section{Introduction}

Tropical vegetation accounts for the majority (60\%) of terrestrial gross primary productivity (GPP), the largest component of the carbon budget, e.g., [1-5]. Although tropical ecosystems play a critical role in the global carbon budget, our understanding of local and regional variability in gross primary production (GPP) is severely limited. These limitations arise due to the complexity of tropical ecosystems, as well as difficulties collecting and scaling data from systems such as eddy covariance flux instruments e.g., [3,6-10]. Satellite-based measurements of solar-induced fluorescence (SIF) developed in recent years are providing a new tool to measure photosynthetic activity from local to global scales. SIF is a by-product of the photosynthetic process, thus is mechanistically coupled to vegetation functioning in contrast to optical reflectance-based vegetation indices (VIs), such as the normalized difference vegetation index, which is often used to model or predict productivity [9,11-17]. SIF data from satellite platforms have been demonstrated to be related to plant photosynthetic functioning, have been shown to scale linearly with modelled and flux tower GPP, have empirical links with crop and deciduous forest GPP in temperate zones, and captured differences in relative productivity of different vegetative classes in temperate regions [11,12,14,18-29].

Studies also suggest SIF is an earlier indicator of vegetation stress than other remote sensing vegetative health indices [20,30-37]. Global scale studies utilizing satellite-based SIF measurements and vegetation classes based on the International Geosphere Biosphere Programme (IGBP) classifications have shown significant vegetation class-specific SIF GPP relationships, except for tropical evergreen broadleaf forest (EBF) $[12,15,28,29,38-42]$. Li, Xiao [41], in particular, examined the vegetation class-specific SIF for eight vegetation classes for the entire globe (deciduous broadleaf forest (DBF), EBF, grasslands (GRA), savanna (SAV), evergreen needleleaf forest (ENF), open shrubland (OSH), crop (CRO) and mixed forests (MF)) and found significant differences in SIF among some classes at global scale as well as SIF GPP relationships for all but EBF [42]. Thus, the SIF GPP relationship remains elusive for tropical forests (EBF) and unexamined for other vegetation types, such as DBF, GRA, $\mathrm{SAV}$ in the tropical regions. There is a consensus in the literature that improving our understanding of regional photosynthetic activity in tropical regions is urgent and SIF has the potential for addressing the gaps in our knowledge by improving characterization of productivity of tropical vegetation types at multiple scales [12,13,21,43-45], however, of the studies utilizing satellite-based SIF in South America, the focus has only been on Amazon evergreen broadleaf forest (EBF) e.g., [22]. Thus, other tropical vegetation and areas outside the Amazon are relatively unstudied.

Tropical vegetation, including tropical forests, appear to have seasonal cycles, yet the magnitudes, timing, and seasonal variation in carbon fluxes, greenness, GPP, leaf area index (LAI), structural changes, for example, are more complex than those observed in more temperate regions [46-49] due to the less pronounced cycles and the high degree of biodiversity in tropical regions [9,35,39,40,50-54]. Vegetation phenology influences spatiotemporal variability of ecosystem productivity and the measures of seasonality are related to fluxes in the carbon cycle, i.e., GPP responds to timing of seasons [9,30,55-59]. Understanding phenology of tropical vegetation, and tropical forests in particular, is critical to understanding the current functioning of tropical biomes and predict responses to a changing climate [2,4,47,60-63]. Currently, our understanding of tropical vegetation seasonality and seasonality response to different environments remains uncertain [1,22,49]. While the Amazon tropical forest has been studied at multiple scales, no studies have yet analyzed seasonal cycles of SIF $_{d}$ in Amazon tropical forests in relation to other, lesser studied vegetation classes and biomes $[47,49,63]$. Past studies utilizing VIs have suggested that the seasonality of photosynthesis in the Amazon is related to leaf phenology responses to high light availability in the dry season triggering a "green up" [63-65], 
but recent studies employing SIF from satellites [35], enumerating sun-sensor geometry and the atmospheric contamination of VIs [64,66-68] have questioned the "green up" results. Satellite-based VIs have been used widely in past studies to explore and understand the seasonal rhythms and phenology as well as drivers, again mostly focused on temperate regions and tropical forests in the Amazon. The remaining questions regarding Amazonian tropical forest phenology, the lack of investigation of other vegetation and regions in Brazil, coupled with recent advancements in dedicated SIF instrumentation onboard satellites, improved spectral resolution, and improvements in data processing and retrieval techniques prompt us to address phenology of different vegetation types across Brazil using satellite SIF [15,27,28,42,51,69-71].

Temperature (T) and vapor pressure deficit (VPD) are influential factors affecting photosynthesis and are important inputs to model productivity [72-76]. As temperature increases, generally, SIF decreases, especially at very high temperatures which increase non-photochemical quenching (NPQ) and excess absorbed energy is given off as heat by the plant $[13,77,78]$. Higher VPD levels induce water stress and usually indicate higher temperature and lower soil moisture conditions, also triggering an increase in NPQ and reducing SIF [79]. Considering the relationships of $\mathrm{T}$ and VPD to productivity is challenging in the tropics due to sparse or scale mismatched data, and data issues become increasingly complex across tropical spatial gradients containing multiple vegetation types $[35,47,50,80]$. Studies have examined temperature, water availability and VPD as drivers of satellite-based SIF in temperate regions and where ground-based measurements or climate data have been co-located and show resulting SIF-GPP relationships are reduced in high temperature or high VPD $[13,42,81,82]$. Environmental conditions, including water availability and VPD, have also been examined in relation to satellite-based SIF in the Amazon and correlations were found between water stress conditions and increased variability in SIF measurements, yet specific relationships among VPD, $\mathrm{T}$, and SIF remain uncertain in Amazon tropical forests and unexamined for other vegetation and biomes $[22,35,83,84]$. Measurements of canopy temperature $\left(T_{c a n}\right)$ have been shown to differ from air temperature $\left(\mathrm{T}_{\text {air }}\right)$ in a tropical forest canopy by as much as 7 degrees Celsius and display better agreement with GPP [85].

Brazil contains 19\% of the world's flora, the world's largest area of tropical forest, the highest carbon stocks and thus contributes significantly to global productivity, terrestrial biomass, and biodiversity $[4,35,62,75,86-89]$. Among the six biomes of Brazil (Amazon, Atlantic Forest, Caatinga, Cerrado, Pampa, and Pantanal), most studies are focused on the Amazon [3,90-94]. Brazil's tropical savanna is the second most dominant vegetation cover at an estimated $20-35 \%$ and it contains the region considered to be the most biodiverse savanna in the world $[90,95,96]$. Savanna ecosystems in Brazil have been identified as biodiversity hotspots and critical carbon sinks yet they are some of the most endangered ecosystems in the world with conversion to agriculture, fires, and clearing of vegetation exceeding the rate of deforestation in the Brazilian Amazon [90-98]. For these reasons, studies examining tropical forest and savanna productivity in Brazil have dominated the research landscape. Each Brazilian biome, however, is a mosaic of vegetation types, and in addition to tropical forests and savannas, include deciduous broadleaf forest, grasslands, and woody savannas among others.

Previous studies examining SIF in the tropics have primarily focused on filtering SIF data for the single vegetation class evergreen broadleaf forest (EBF) for comparison to SIF and other remote sensing indices from satellites, flux tower data, or leaf level measurements or response to climate events such as drought $[22,35,47,60,99-101]$. These studies have taken important steps to understand satellite SIF in relation to GPP, light use efficiency (LUE), and drivers of photosynthetic function (i.e., light availability, water availability, temperature, vapor pressure deficit) and to interpret SIF data (i.e., sensor geometry, canopy structure, sensor degradation). In our approach, however, we investigated the degree to which satellite-based SIF may or may not capture differences in magnitude and seasonality among tropical vegetation classes that exist within similar climatic and geographic regions as a means to understand SIF before filtering or combining vegetation classes or making comparisons to other quantities. To our knowledge, no studies have been conducted to examine the biome-level photosynthetic activity of 
EBF outside the Amazon or have compared SIF of EBF to other vegetation classes in Brazil. Therefore, an examination of the spatiotemporal patterns of SIF for different vegetation classes within and among biomes is an important step to understanding the relative productivity and drivers of tropical vegetation SIF beyond the Amazonian tropical forest $[47,60,100]$.

We examined three years of Orbiting Carbon Observatory-2 (OCO-2) SIF data in the six Brazilian biomes (Amazon, Atlantic Forest, Caatinga, Cerrado, Pampa, and Pantanal) to answer the following: (1) how does SIF in vegetation classes within and across Brazilian biomes differ? (2) What is the relationship (strength and direction) of SIF with canopy temperature $\left(\mathrm{T}_{\text {can }}\right)$, air temperature $\left(\mathrm{T}_{\text {air }}\right)$, and vapor pressure deficit (VPD) among vegetation classes within and across biomes? (3) How does the phenology of SIF (duration and amplitude of seasonal integrated SIF) compare among vegetation classes within and across biomes?

\section{Materials and Methods}

\subsection{Study Areas: Brazilian Biomes}

In this study, biome refers to the six main biomes of Brazil as defined by the Ministério do Meio Ambiente (MMA) as regions sharing morphoclimatic and phytogeographical characteristics: Amazon, Caatinga, Cerrado, Pampa, Pantanal, and Atlantic Forest [102]). Figure 1 shows the Brazilian biome limits utilized in this study. These biomes are used as a large spatial scale basis for comparisons of the high resolution satellite-based SIF measurements across regions for the whole country of Brazil, which covers an area of about 850 million ha [103]. Table S1 shows a list of all abbreviations used in the study.

The Amazon is the largest biome (about 50-60\% of all Brazil) with a humid tropical climate, low seasonal temperature variability, approximately 1000-2000 mm of annual precipitation, containing approximately half the world's tropical rainforest, and critical for biodiversity and the global carbon balance [84,104,105]. The Cerrado is second in area to the Amazon (about 22-25\%), with about 1200-1800 mm of precipitation, experiences seasonal periods of tropical followed by dry climate, and has a great diversity of vegetation types and canopy covers, with savanna, woody savanna, dry grasslands, wet grasses, and tropical forests, often heavily fragmented for agriculture [96,97,106-108]. The Pantanal is one of the largest wetlands in the world $\left(160,000 \mathrm{~km}^{2}\right)$ with a dynamic yearly flooding regime and is a United Nations Educational, Scientific and Culture Organization (UNESCO) World Heritage site containing tropical wetlands with arid tropical species alongside dry shrubland and grasses as well as xeric species [109-111]. The Pantanal contains a unique hydrologic structure of seasonal inundation fed by the upper Paraguay River and average yearly rainfall of 1000-1400 mm, alternating patterns of salt and freshwater lakes (bahias and salinas), and the highest species diversity and concentration of wildlife in the world, yet it makes up only about $2 \%$ of the area of Brazil [109,110,112-115]. Despite often being referred to as a desert, the Caatinga is a semi-arid region, making up about $10 \%$ of the country, has only about $700 \mathrm{~mm}$ of rainfall per year, falling sometimes erratically with high temperatures and low humidity [116,117]. and the dominant vegetation is woody shrub land and savanna with abundant xerophytic species, but contains mosaics of seasonally dry tropical forests and is one of the most populated semi-arid regions of the world [96,103,116-119]. The Atlantic Forest covers a wide longitudinal area and has been heavily fragmented to only about $10 \%$ of the native vegetation remaining after once having about 150 million ha of rainforest [88,120]. The Atlantic Forest makes up about 13\% of the country's area and much of this is along the Atlantic coast having vegetation ranging from deciduous and tropical forest to mangroves and vast managed forestry plantations, other agriculture, and urban areas [88,120-123]. The average rainfall in the Atlantic forest varies greatly from coastal areas (more than $4000 \mathrm{~mm} /$ year) to inland ( 1000 mm/year), along elevation gradients ( 1600 mm/year at sea level to up to $3600 \mathrm{~mm} /$ year in high altitude mountain regions) and along the latitudinal expanse of the biome [120]. The Pampa is the southernmost border biome, occupies approximately $2 \%$ of Brazil, and has a transition from tropical to temperate climate, thus having four seasons, supporting 
grasslands and deciduous forest, and a large amount of agricultural development [124,125]. The Pampa lies within the South temperate zone with subtropical and temperate climates averaging approximately 1200-1600 mm/year precipitation [124].

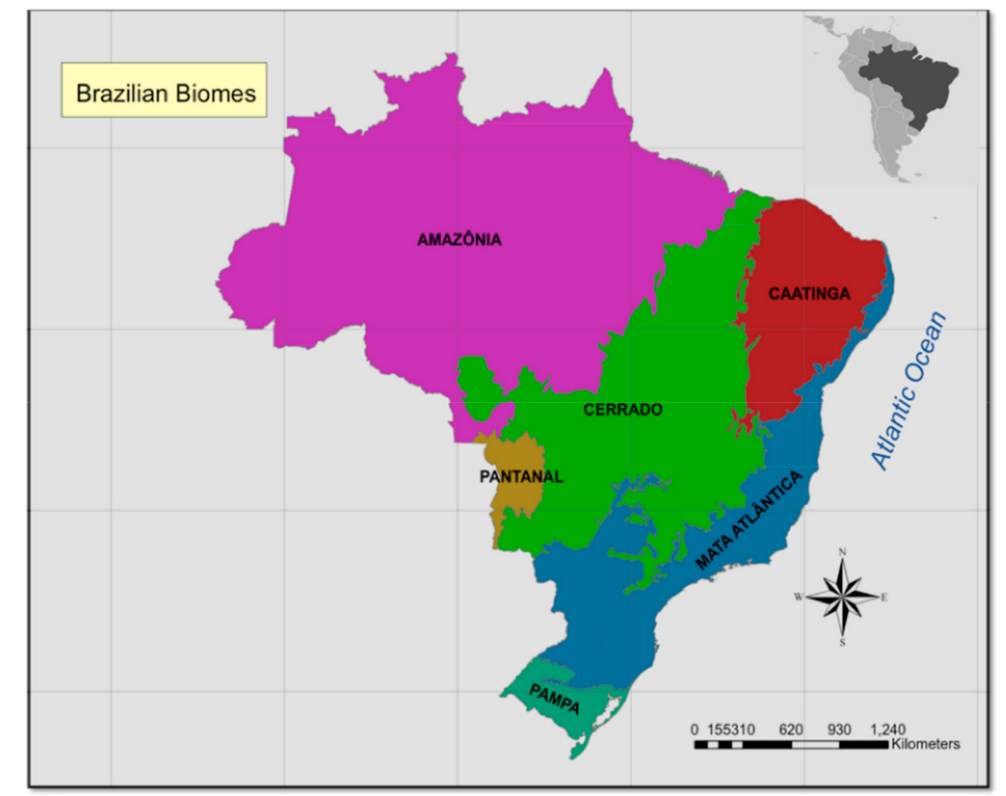

Figure 1. Map of Brazilian biome limits for the study. The six biomes are shown in color on the large map. The inset in the upper right corner is South America with the shaded region representing the extent of Brazil.

\subsection{Orbiting Carbon Observatory-2 (OCO-2) SIF}

Launched in 2014, the Orbiting Carbon Observatory-2 (OCO-2, NASA) satellite collects SIF observations globally, offering the opportunity to measure photosynthetic activity of vegetation at higher resolution than was possible before and to employ them to address gaps in knowledge about GPP and carbon fluxes in the tropics. OCO-2 based SIF measurements provide superior spatial and spectral resolution, data acquisition techniques, and retrieval precision than previous satellite-based SIF measurements. This allows for improved validation and better determination of SIF-GPP relationships [27,44,100]. OCO-2 collects spectral data from 757 to $775 \mathrm{~nm}$ (the Oxygen absorption-A band; $\mathrm{O}_{2} \mathrm{~A}$ ) at approximately 1330 local time (LST) allowing accurate, high resolution retrievals of instantaneous solar-induced fluorescence (SIF) within the Fraunhofer lines at 757 and $771 \mathrm{~nm}$ at a spectral resolution of $0.042 \mathrm{~nm}(\mathrm{FWHM}=0.042 \mathrm{~nm})$ [44]. OCO-2 acquires 24 spectra per second producing eight cross-track spectra each covering about $2 \mathrm{~km} \times 1.3 \mathrm{~km}$ spatial area, called a footprint, over a narrow swath width with maximum of approximately $10 \mathrm{~km}$. At the Equator, the swath width narrows due to slit rotation and the instrument records spectra of only one ground footprint with all eight independent cross-track spectra [15]. The revisit period is every 16 days. Through 2 July 2015 each revisit time alternated between glint and nadir mode for the instrument, thus the repeat time for a set of nadir measurements is every 32 days. Since 2 July 2015, the instrument alternates modes for every orbit. Nadir mode measurements are recommended for studies such as this one because it follows a similar ground track each revisit time (allowing detection of temporal changes), has a higher spatial resolution, better signal-to-noise ratio and more consistent measurements under varying atmospheric conditions and topography than does glint mode $[15,27,44,126,127]$. OCO-2's coverage is global, however, there are gaps between the points and swaths. Continuous spatial coverage is sacrificed for the fine spatial sampling of each OCO-2 footprint. This fine spatial sampling and high resolution SIF measurements provide the opportunity to more accurately address SIF of specific vegetation classes within and across biomes than previous satellite-based platforms used for SIF. Nonetheless, while 
OCO-2 SIF data have high spectral and spatial resolution, individual footprints are noisy, thus analyses in this study follow previous studies utilizing averaging in space and time $[9,12,15,23,42,44,128]$.

The OCO-2 SIF Lite product (version $8 \mathrm{r}$, " $\mathrm{r}$ " indicating retrospective dataset) data from September 2014-October 2017 for South America was downloaded and processed. The entire OCO-2 dataset is missing August 2017 due to the sensor not collecting during that period. The data were read in, filtered for nadir mode, and relevant variables, such as IGBP class, VPD, $2 \mathrm{~m}$ temperature (air temperature, $\mathrm{T}_{\text {air }}$ ), and skin temperature (canopy temperature, $\mathrm{T}_{\text {can }}$ ) were retained for all OCO- 2 footprints from the dataset. The source of these environmental variables is the European Centre for Medium-Range Weather Forecasts (ECMWF) and is included in the OCO-2 product. Brazil OCO-2 SIF footprints were co-located with shapefiles of Brazilian biomes from Ministério do Meio Ambiente (MMA, http://mapas.mma.gov.br/i3geo/datadownload.htm [102]) and all footprints in Brazil extracted and flagged for biome location. Instantaneous SIF $\left(\mathrm{SIF}_{\text {inst }}\right)$ was calculated using the average of instantaneous SIF measured at $757 \mathrm{~nm}$ and instantaneous SIF at $771 \mathrm{~nm}$ times a factor of 1.7 based on the OCO-2 Data Product User's Guide and previous literature $[15,28,126,129,130]$ as follows:

$$
\mathrm{SIF}_{\text {inst }}=\frac{\mathrm{SIF}_{757 \mathrm{~nm}}+1.7 \mathrm{SIF}_{771 \mathrm{~nm}}}{2}
$$

SIF $_{\text {inst }}$ was normalized for differences in sun angle and daily changes by application of the daily mean correction factor (DCF), which is a time averaged first order approximation of a daily average $\mathrm{SIF}_{\mathrm{d}}[14,126,130,131]$. The DCF varies with time and latitude because these relate to the variation of the solar zenith angle (SZA) and length of the day, thus having a seasonal cycle. Although this cycle is weaker in the tropics than higher latitudes, applying the DCF to SIF is recommended for examination of seasonal cycles, comparing SIF across large spatial scales, and when examining OCO-2 based SIF to other products with different collection times [15,27,131,132].The DCF approximately accounts for the length of day and variability of the solar zenith angle (sza) using pure geometric incoming light scaling for the location in ten-minute time steps. $\operatorname{SIF}_{d}$ is calculated with the following equation

$$
\operatorname{SIF}_{\mathrm{d}}=\frac{\operatorname{SIF}_{757 \text { or } 71 \mathrm{~nm}}}{\cos \left(\operatorname{sza}\left(\mathrm{t}_{\mathrm{m}}\right)\right)} \int_{\mathrm{t}}^{\mathrm{t}=\mathrm{t}_{\mathrm{m}}-12 \mathrm{~h}} \cos (\operatorname{sza}(\mathrm{t})) \mathrm{dt}
$$

where sza is the solar zenith angle from the OCO-2 dataset and $t_{m}$ is the time of measurement $[14,126,130]$

The programming for downloading and processing of OCO-2 data was completed using the interactive data language (IDL; Harris Geospatial, Inc., Boulder, Co.).

\subsection{Statistical Analysis for Differences in Mean SIF $F_{d}$ between Biomes and Vegetation Classes}

The monthly average of all $\mathrm{SIF}_{\mathrm{d}}$ observations within a biome were calculated for all vegetation classes aggregated (AVC) and an analysis of significant differences in the overall three year mean $\operatorname{SIF}_{d}$ of the biomes was performed to investigate differences in SIF $_{d}$ measured among biomes. To compare the variability of SIF $_{d}$ measurements among biomes, the coefficient of variation $(C V)$ of monthly average $\mathrm{SIF}_{\mathrm{d}}$ was calculated for each biome and an analysis of differences performed. The data were tested for normality and significant differences by examining the residuals, qq-plot, and histogram of residuals of a two-way analysis of variance (ANOVA) and post hoc testing of differences was performed using Tukey's honestly significant difference test.

We then subset and filtered $\mathrm{SIF}_{\mathrm{d}}$ observations in each biome for key vegetation classes based on the IGBP (Table S2, [56]): Deciduous Broadleaf Forests (DBF), Evergreen Broadleaf Forests (EBF), Grasslands (GRA), Savannas (SAV), and Woody Savannas (WSAV). The average of all $\mathrm{SIF}_{\mathrm{d}}$ observations occurring in each month within a biome were calculated for each of the key vegetation classes. These natural (non-crop) classes composed the five largest proportions of $\operatorname{SIF}_{\mathrm{d}}$ measurements calculated in biomes which are expected to have distinct SIF $_{\mathrm{d}}$ signals and phenological cycles. Exclusion of Open Shrublands (OSH) and Closed Shrublands (CSH), for instance, was due to the mixed deciduous and evergreen foliage contained in these classes (Table S2) in conjunction with low proportions of $\mathrm{SIF}_{\mathrm{d}}$ measurements. To investigate differences in SIF $_{d}$ measured among vegetation classes within biomes and to test for 
interaction between biome and vegetation class, statistical analysis of significant differences in the mean $\mathrm{SIF}_{\mathrm{d}}$ were performed following the procedures comparing $\mathrm{AVC} \mathrm{SIF}_{\mathrm{d}}$ among biomes (previous paragraph). Table S3 provides the values for the distribution of OCO-2 SIF observations by biome and vegetation class for the study.

\subsection{Correlation with Environmental Variables: $T_{\text {can }}, T_{\text {air }}, V P D$}

To investigate the strength and direction of these relationships, Spearman correlations were calculated between $\operatorname{SIF}_{d}$ and the environmental variables: $T_{\text {skin }}, T_{2 m}$, VPD for each vegetation class in each biome. All statistical analysis and figures from statistical and seasonality analysis were completed in R version 3.4.2, RStudio version 1.0.153 and the packages: dplyr, tidyverse, ggplot2, and zoo [133-137].

\subsection{Seasonality Metrics Extraction}

In order to explore the behavior that may be masked by analysis of means, especially temporal patterns, we undertook an analysis of seasonality for the vegetation classes in the biomes. We generated time series of vegetation-specific $\operatorname{SIF}_{d}$ for each biome to inspect the interannual variability of $\mathrm{SIF}_{\mathrm{d}}$ measurements (Figure S11). Based on this inspection, we determined that the Pampa DBF data had too many missing consecutive months for the study period to be reliable. We then applied the TIMESAT algorithms to each of the other vegetation class' $\mathrm{SIF}_{\mathrm{d}}$ time series for each biome to calculate seasonality metrics $[47,138]$. TIMESAT was designed to analyze time series data from satellite sensors and generate seasonality metrics such as start of season, end of season, peak of season, season length, base value, maximum value, amplitude value, rates of increase and decrease, large (total) and small (pulse) integrals $[138,139]$ (Figure 2). The time series of SIF $_{d}$ for each vegetation class within each biome were smoothed using the median of a moving window by more than one standard deviation. After the time series were smoothed, we used the TIMESAT double logistic functions fitting method setting. The average of the seasonality metrics for seasons detected over the three-year study period $(n=2)$ in each time series was calculated to represent annual metrics for $\operatorname{SIF}_{\mathrm{d}}$ seasonality of each vegetation class in each biome. A sample diagram of raw and fit data is shown in Figure 2. The algorithm determines the base as the average of the left and right minimum values, and the amplitude as the difference between the base value and the maximum (labels $d$ and g, respectively, Figure 2). The time for begin and end of season are determined using 0.5 of the amplitude from the left and right, respectively, following methods for determining seasonality parameters in the literature $[47,56,140]$.

From TIMESAT results, the per-season base integrated $\mathrm{SIF}_{d}$ and the pulse integrated $\mathrm{SIF}_{\mathrm{d}}$ were analyzed to quantify annual $\operatorname{SIF}_{\mathrm{d}}$ productivity for each vegetation class in each biome. The length of season (LOS) in days was calculated for each vegetation class in each biome. The mean LOS for a biome was calculated as the average of the $\mathrm{SIF}_{\mathrm{d}}$ LOS of DBF, EBF, GRA, SAV and WSAV SIF ${ }_{\mathrm{d}}$ within that biome. We examined differences in means of LOS among biomes utilizing the Kruskal Wallace test and Pairwise Wilcoxon Tests. Additionally, we used a generalized linear model (GLM) to determine if length of $\operatorname{SIF}_{d}$ season would explain the variation found in the total integrated $\operatorname{SIF}_{d}$. 


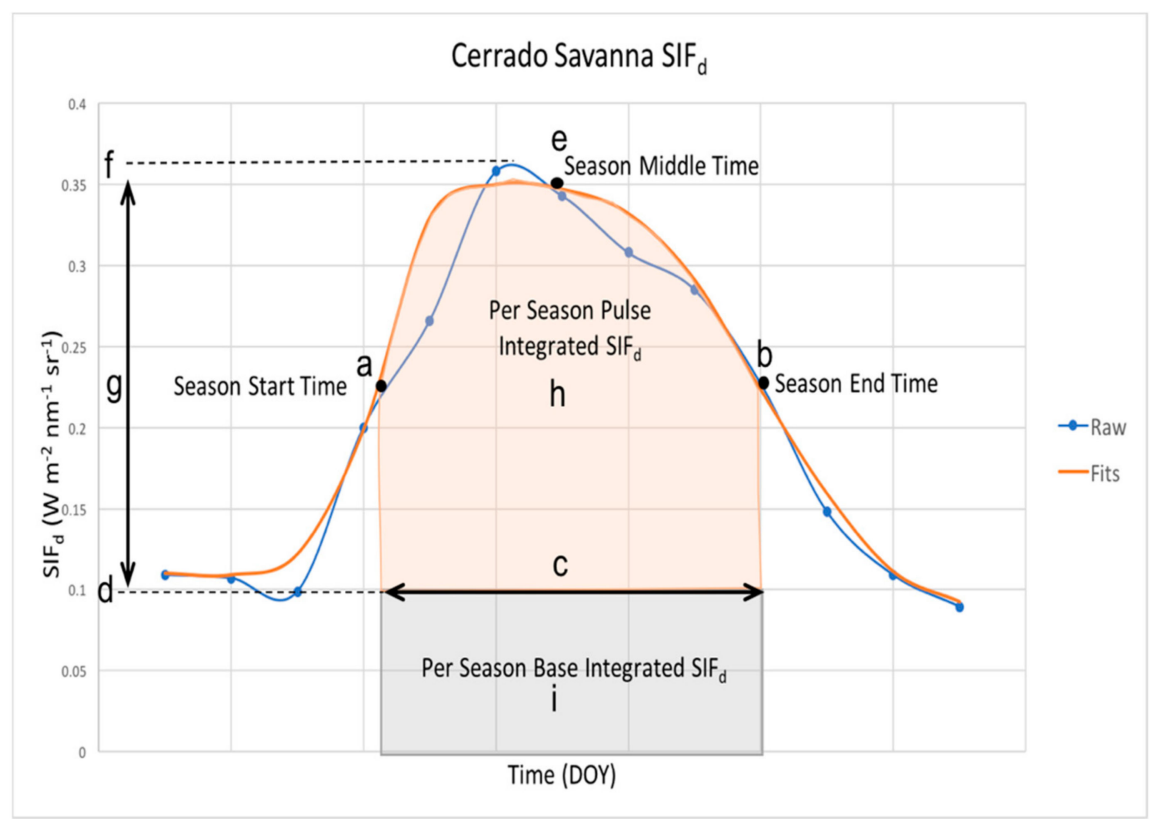

Figure 2. Example diagram of TIMESAT seasonality of $\mathrm{SIF}_{\mathrm{d}}$ metrics. Based on raw and fit data for the

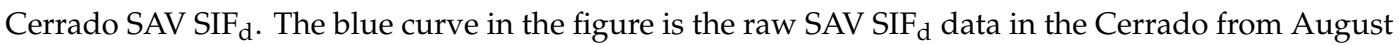
2015-August 2016 (post interpolation if any were needed) and the fit data is plotted in orange. The area under the fit curve yields integrated $\mathrm{SIF}_{\mathrm{d}}$ for the base and seasonal pulse, the SIFd values for start, max, and end of season are calculated, and the timing of start, end, and maximum time are identified. From these, the length of season can also be calculated. (a) season start time, (b) season end time, (c) length of season, (d) base value, (e) time of middle of season, (f) maximum value, (g) amplitude, (h) seasonal pulse integrated value, (i) base integrated value. Adapted from Eklundh and Jönsson [139].

\section{Results}

\subsection{Comparison of $\operatorname{SIF}_{d}$ among Biomes}

We found that Amazon AVC SIF ${ }_{\mathrm{d}}$ is significantly different (mean $=0.38 \mathrm{Wm}^{-2} \mathrm{~nm}^{-1} \mathrm{sr}^{-1}$; Figure 3 and Table S4) than all other biomes (ANOVA, $p<0.001$; Tukey's HSD, $p<0.001$; Table S5) and the Caatinga AVC SIF $\mathrm{d}$ is significantly different (mean $=0.13 \mathrm{Wm}^{-2} \mathrm{~nm}^{-1} \mathrm{sr}^{-1}$; Figure 3 and Table S4) than all other biomes (ANOVA, $p<0.001$; Tukey's HSD, $p<0.001$; Table S5), as might be expected based on prior understanding of biomass and chlorophyll content of vegetation in the biomes. No significant differences in AVC SIF $\mathrm{d}_{\mathrm{d}}$ were found among the Atlantic Forest $\left(0.24 \mathrm{Wm}^{-2} \mathrm{~nm}^{-1} \mathrm{sr}^{-1}\right.$; Figure 3 and Table S4), Cerrado (0.24 Wm $\mathrm{Wm}^{-1} \mathrm{sr}^{-1}$; Figure 3 and Table S4), Pampa $\left(0.21 \mathrm{Wm}^{-2} \mathrm{~nm}^{-1} \mathrm{sr}^{-1}\right.$; Figure 3 and Table S4), and Pantanal (0.25 Wm $\mathrm{Wm}^{-2} \mathrm{nr}^{-1}$; Figure 3 and Table S4) biomes' AVC SIF . We found OCO-2 captured the lower spatial variability measured using CV of mean SIF $_{d}$ in Amazon AVC SIF (mean CV $=0.46, p<0.001$ ) than all other biomes and the higher CV for the Caatinga (mean CV = 1.39, $p<0.01$ ). No significant differences in variability of $\mathrm{SIF}_{\mathrm{d}}$ were found among the Atlantic Forest (mean $\mathrm{CV}=0.77$ ), Cerrado (mean CV =0.78), Pampa (mean CV =0.72), and Pantanal (mean CV =0.63) biomes. Figures S1-S7 show plots of the residuals versus fitted values, qq-plot, and histogram of residuals of the two-way ANOVA. 

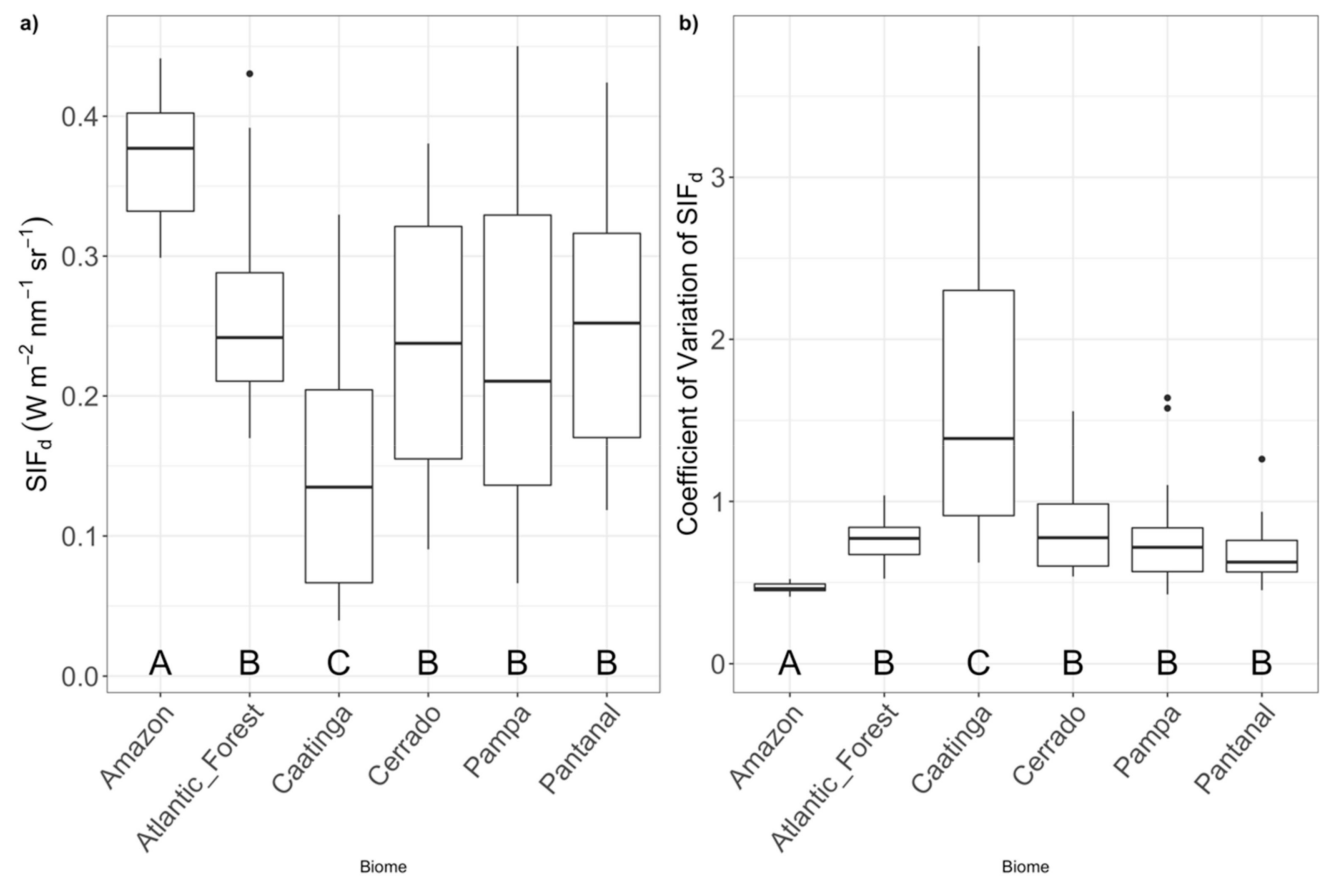

Figure 3. (a) Differences in (a) $\mathrm{SIF}_{\mathrm{d}}$ for all vegetation classes aggregated (AVC) for each biome. (b) CV of monthly $\mathrm{SIF}_{\mathrm{d}}$ for all vegetation classes aggregated (AVC) for each biome. Boxplots representing the minimum, 1st quartile, mean, 3rd quartile, and maximum $\mathrm{SIF}_{\mathrm{d}}$ for vegetation classes in each Brazilian biome are shown. Outliers are represented by dots. Significant differences in means indicated by group symbols A, B, C.

\subsection{Comparison of $\operatorname{SIF}_{d}$ among Vegetation Classes within Biomes}

Our analysis of mean OCO-2 $\mathrm{SIF}_{\mathrm{d}}$ measurements distinguished forest from other classes' $\mathrm{SIF}_{\mathrm{d}}$ in the cases of EBF, but not DBF. In every biome, we found EBF SIF ${ }_{\mathrm{d}}$ to be significantly different than all other vegetation classes (Tukey's HSD, $p<0.001$ ) Figure 4, panels a-f, Tables S4 and S6). Amazon EBF $\mathrm{SIF}_{\mathrm{d}}$ had the highest mean of any class in any biome (mean $=0.38 \mathrm{Wm}^{-2} \mathrm{~nm}^{-1} \mathrm{sr}^{-1}$ ) (Figure 4, panels a-f, Tables S4 and S6). However, DBF $\mathrm{SIF}_{\mathrm{d}}$ was not significantly different than GRA, SAV, or WSAV in any of the biomes. Among the non-forest classes, mean SIF $_{d}$ analysis based on measurements from OCO-2 were partially able to distinguish GRA SIF ${ }_{d}$ from SAV SIF , but not able to differentiate SAV SIF from

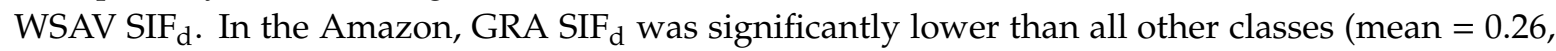
$p<0.01)$ Figure 4 panel a Tables S4 and S6). In the Atlantic Forest, Caatinga, and Cerrado GRA SIF (mean $=0.25,0.14,0.20 \mathrm{Wm}^{-2} \mathrm{~nm}^{-1} \mathrm{sr}^{-1}$, respectively; Table S4) was not significantly different than SAV $\operatorname{SIF}_{\mathrm{d}}$ (mean $=0.25,0.16,0.23 \mathrm{Wm}^{-2} \mathrm{~nm}^{-1} \mathrm{sr}^{-1}$, respectively; Table S4) but, GRA SIF ${ }_{\mathrm{d}}$ in the Pampa and Pantanal biomes (mean $=0.23,0.22 \mathrm{Wm}^{-2} \mathrm{~nm}^{-1} \mathrm{sr}^{-1}$, respectively; Table S4) were significantly lower than SAV SIF ${ }_{\mathrm{d}}$ (mean $=0.27,0.25 \mathrm{Wm}^{-2} \mathrm{~nm}^{-1} \mathrm{sr}^{-1}$, respectively; Tukey's HSD, $p<0.05$ ) (Figure 4, panels $b-f$, Tables S4 and S6). No difference was found among SAV, and WSAV SIF $F_{d}$ in any of the biomes. The results of a two-way ANOVA showed there was a significant interaction between biome and vegetation class on $\operatorname{SIF}_{d}$ (ANOVA F $\left.(20,1056)=1.922\right)$. Therefore, to further investigate the comparison means of SIF $_{d}$ of vegetation classes across biomes would require an exploration of the combination of biome and vegetation class as main effects. 


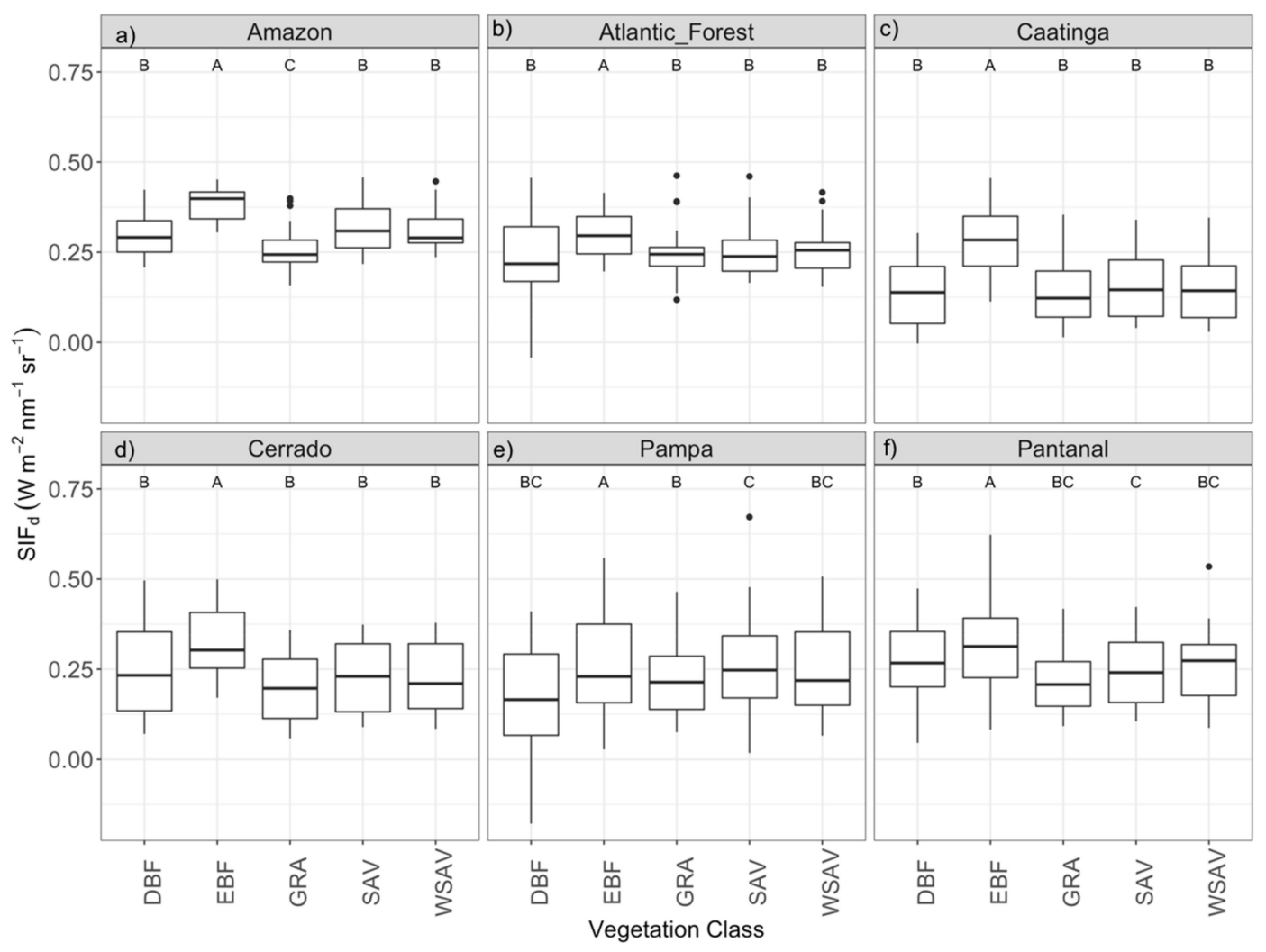

Figure 4. Differences in monthly mean $\mathrm{SIF}_{\mathrm{d}}$ among vegetation classes within each biome. Boxplots representing the minimum, 1st quartile, mean, 3rd quartile, and maximum $\mathrm{SIF}_{\mathrm{d}}$, for vegetation classes in each Brazilian biome are shown. Outliers are represented by dots. Significant differences in means indicated by group symbols A, B, C.

\subsection{Monthly Mean $\operatorname{SIF}_{d}$ Correlations to $T_{c a n}, T_{a i r}$, and VPD}

In the Amazon, DBF and EBF $\mathrm{SIF}_{d}$ were not significantly correlated with $\mathrm{T}_{\text {can }}, \mathrm{T}_{\text {air }}$ or VPD. The range of values for $\mathrm{T}_{\mathrm{can}}, \mathrm{T}_{\mathrm{air}}$, and $\mathrm{VPD}$ for $\mathrm{DBF}$ and $\mathrm{EBF}$ were smaller than other vegetation classes and the range of SIF $_{d}$ values slightly smaller (Figures S2-S4). Amazon GRA, SAV and WSAV SIF were significantly negatively correlated with $\mathrm{T}_{\text {can }}, \mathrm{T}_{\text {air }}$, and VPD ( $\mathrm{r}$ between -0.72 and $-0.35, p<0.05$, Table 1). Amazon GRA, SAV, and WSAV $\mathrm{SIF}_{\mathrm{d}}$ had the strongest correlation with VPD $(\mathrm{r}=-0.81$, $\mathrm{r}=-0.6, \mathrm{r}=-0.55$, respectively, $p<0.001)$ and less correlated with $\mathrm{T}_{\text {air }}(\mathrm{r}=-0.72, \mathrm{r}=-0.35, \mathrm{r}=0.40$, respectively, $p<0.001)$ and $\mathrm{T}_{\text {can }}(\mathrm{r}=-0.7, \mathrm{r}=-0.35, \mathrm{r}=0.41$, respectively, $p<0.001)$, which were similar in strength and direction with $\mathrm{SIF}_{\mathrm{d}}$ in these classes. This indicates that variations in $\mathrm{SIF}_{\mathrm{d}}$ are more driven by changes in VPD than to $\mathrm{T}_{\text {can }}$ or $\mathrm{T}_{\text {air }}$. Correlations between Amazon GRA SIF $\mathrm{d}_{\mathrm{d}}$ are stronger than SAV and WSAV SIF $_{\mathrm{d}}$ (Table 1).

We found few significant relationships of vegetation class $\mathrm{SIF}_{d}$ with $\mathrm{T}_{\mathrm{can}}, \mathrm{T}_{\mathrm{air}}$, or VPD in the Atlantic Forest, but all those found were positive. Atlantic Forest EBF $\operatorname{SIF}_{\mathrm{d}}$ was significantly related to $\mathrm{T}_{\text {can }}, \mathrm{T}_{\text {air }}$, and VPD $(\mathrm{r}=0.71,0.74$, and $0.6, p<0.001$, respectively; Table 1$)$. WSAV SIF $\mathrm{d}_{\mathrm{d}}$ was positively correlated with $\mathrm{T}_{\text {can }}$ and $\mathrm{T}_{\text {air }}(\mathrm{r}=0.45,0.54, p<0.001$, respectively (Table 1$)$, but not with VPD. No other correlations among $\operatorname{SIF}_{\mathrm{d}}$ and $\mathrm{T}_{\mathrm{can}}, \mathrm{T}_{\text {air }}$, or VPD were found in the Atlantic Forest.

In the Caatinga all vegetation classes' $\mathrm{SIF}_{\mathrm{d}}$ were significantly negatively correlated to $\mathrm{T}_{\mathrm{can}}$ ( $\mathrm{r}$ between -0.51 and $-0.82, p<0.01$, Table 1$)$ and $\mathrm{T}_{\text {air }}$ ( $\mathrm{r}$ between -0.37 and $-0.75, p<0.05$ : Table 1 ) and with VPD ( $\mathrm{r}$ between -0.57 and $-0.85, p<0.01$; Table 1). Caatinga SIF $_{\mathrm{d}}$ in all classes (DBF, EBF, GRA, SAV, WSAV) had the strongest relationship with VPD ( $\mathrm{r}=-0.57,-0.71,-0.85,-0.81$, and -0.77 , $p<0.001$, respectively; Table 1) followed by $\mathrm{T}_{\text {can }}(\mathrm{r}=-0.51 p<0.01, \mathrm{r}=-0.69,-0.82,-0.85,-0.78$, and $-0.74, p<0.001$, respectively: Table 1$)$, then $\mathrm{T}_{\text {air }}(\mathrm{r}=-0.37 p<0.01, \mathrm{r}=-0.57,-0.75,-0.73$, and $-0.66, p<0.001$, respectively; Table 1). Caatinga $\mathrm{DBF} \mathrm{SIF}_{\mathrm{d}}$ has the weakest correlations with $\mathrm{T}_{\text {can }}$, 
$\mathrm{T}_{\mathrm{air}}$ and VPD of the vegetation classes in the Caatinga. $\mathrm{T}_{\mathrm{can}}, \mathrm{T}_{\mathrm{air}}$, and VPD relationship strengths are more similar for EBF, GRA, SAV, and WSAV SIF ${ }_{d}$ in the Caatinga than for DBF and EBF $\operatorname{SIF}_{d}$ with $\mathrm{T}_{\text {can, }}, \mathrm{T}_{\text {air }}$.

Relationships of vegetation class $\operatorname{SIF}_{\mathrm{d}}$ with climatic variables are similar in the Cerrado to those in the Caatinga and the ranges of values for $\mathrm{T}_{\mathrm{can}}, \mathrm{T}_{\mathrm{air}}$, and VPD are more similar for the Caatinga and Cerrado than for the other biomes (Table 1, Figures S2-S4). In the Cerrado, all vegetation class' SIF $_{d}$ are significantly negatively correlated with $\mathrm{T}_{\mathrm{can}}, \mathrm{T}_{\text {air }}$ and VPD ( $\mathrm{r}$ between -0.50 and $-0.80, p<0.01$; Table 1). Correlations of Cerrado $\mathrm{SIF}_{\mathrm{d}}$ are strongest between VPD and $\mathrm{SIF}_{\mathrm{d}}$ (VPD: $\mathrm{r}$ between -0.69 and $-0.80, p<0.001$ : Table 1 ) in every vegetation class, followed by $\mathrm{T}_{\text {can }}$ ( $\mathrm{r}$ between -0.52 and -0.70 , $p<0.01$ ), then $\mathrm{T}_{\text {air }}\left(\mathrm{r}\right.$ between -0.50 and $-0.61, p<0.01$; Table 1). The Cerrado $\mathrm{SIF}_{\mathrm{d}}$ relationships deviate from the Caatinga in that Cerrado $\mathrm{EBF} \mathrm{SIF}_{\mathrm{d}}$ has weaker relationships with all variables $\left(\mathrm{T}_{\mathrm{can}}\right.$, $\mathrm{T}_{\text {air }}$, and VPD) than the other classes' $\mathrm{SIF}_{\mathrm{d}}$, while we found that $\mathrm{DBF} \mathrm{SIF}_{\mathrm{d}}$ had the weakest relationships with variables for all classes.

In the Pampa, all vegetation class' $\mathrm{SIF}_{\mathrm{d}}$ are significantly positively correlated with $\mathrm{T}_{\text {can }}, \mathrm{T}_{\text {air }}$ and VPD ( $r$ between 0.46 and $0.83, p<0.01$; Table 1 ) in contrast to the negative correlations to $\mathrm{T}_{\text {can }}, \mathrm{T}_{\text {air }}$, and VPD found for all vegetation classes' SIF $_{\mathrm{d}}$ in the Caatinga and Cerrado. The Pampa had the lowest maximum $T_{\text {can }}$ and $T_{\text {air }}$ values of any biome ( $311 \mathrm{~K}$ and $308 \mathrm{~K}$, respectively; Figures $\mathrm{S} 8$ and $\mathrm{S} 9$ ) and $\mathrm{T}_{\text {can }}$ and $T_{\text {air }}$ values reached lower values in the Pampa biome compared to any other biome. DBF $\operatorname{SIF}_{d}$ in the Pampa had the strongest relationship with $\operatorname{VPD}(\mathrm{r}=0.59, p<0.01$; Table 1$)$ while all other vegetation classes (EBF, GRA, SAV, WSAV) were most strongly correlated with $\mathrm{T}_{\text {can }}(\mathrm{r}=0.52 p<0.01,0.77 p<$ $0.001,0.82 p<0.001,0.83 p<0.001$, respectively; Table 1). EBF SIF ${ }_{d}$ in the Pampa showed the lowest correlation to VPD relative to $\mathrm{T}_{\mathrm{can}}$ and $\mathrm{T}_{\mathrm{air}}$, the only vegetation class with the weakest relationship to VPD. Note the DBF sample size was the smallest of all the vegetation classes in all biomes of the study $\left(\mathrm{n}=52\right.$, resulting in $\mathrm{n}=24$ for monthly average $\mathrm{SIF}_{\mathrm{d}}$ ), which may have influenced the results (Table 1 ).

In the Pantanal, no significant relationships were found for any vegetation class' $\operatorname{SIF}_{d}$ with $\mathrm{T}_{\text {can, }}$, $\mathrm{T}_{\mathrm{air}}$, or VPD. Values of $\mathrm{T}_{\text {can }}$ and $\mathrm{T}_{\text {air }}$ were the highest and the range of VPD values was the widest in the Pantanal of all the biomes (Figures S8-S10).

Table 1. Relationships (r values) between monthly $\mathrm{SIF}_{\mathrm{d}}$ and $\mathrm{T}_{\mathrm{can}}, \mathrm{T}_{\text {air }}$, and VPD for vegetation classes in each biome. $p$-values indicated by stars: ${ }^{* * *}=p<0.001,{ }^{* *}=p<0.01,{ }^{*}=p<0.05$, no stars indicate non-significant relationships.

\begin{tabular}{|c|c|c|c|c|c|c|}
\hline \multicolumn{7}{|c|}{$T_{c a n}$} \\
\hline & Amazon & Atlantic Forest & Caatinga & Cerrado & Pampa & Pantanal \\
\hline $\mathrm{DBF}_{\mathrm{SIF}} \mathrm{d}$ & 0.15 & 0.25 & $-0.51 *$ & $-0.70^{* * *}$ & $0.55^{* *}$ & -0.15 \\
\hline EBF SIF ${ }_{d}$ & 0.03 & $0.71^{* * *}$ & $-0.69^{* * *}$ & $-0.52^{* *}$ & $0.52 * *$ & -0.07 \\
\hline GRA SIF $_{\mathrm{d}}$ & $-0.70^{* * *}$ & -0.17 & $-0.82 * * *$ & $-0.58^{* * *}$ & $0.77^{* * *}$ & -0.09 \\
\hline $\mathrm{SAV} \mathrm{SIF}_{\mathrm{d}}$ & $-0.35^{*}$ & 0.19 & $-0.78^{* * *}$ & $-0.60^{* * *}$ & $0.82^{* * *}$ & -0.07 \\
\hline WSAV SIF & $-0.41 *$ & $0.45^{* *}$ & $-0.74^{* * *}$ & $-0.61^{* * *}$ & $0.83^{* * *}$ & -0.04 \\
\hline \multicolumn{7}{|c|}{$T_{a i r}$} \\
\hline & Amazon & Atlantic Forest & Caatinga & Cerrado & Pampa & Pantanal \\
\hline $\mathrm{DBF}_{\mathrm{SIF}}$ & 0.15 & 0.14 & $-0.37^{*}$ & $-0.61^{* * *}$ & $0.55^{* *}$ & -0.13 \\
\hline $\mathrm{EBF} \mathrm{SIF}_{\mathrm{d}}$ & 0.03 & $0.74^{* * *}$ & $-0.57^{* * *}$ & $-0.50^{* *}$ & $0.46^{* *}$ & -0.01 \\
\hline GRA SIF $_{\mathrm{d}}$ & $-0.72 * * *$ & -0.07 & $-0.75^{* * *}$ & $-0.52 * *$ & $0.76^{* * *}$ & -0.06 \\
\hline $\mathrm{SAV} \mathrm{SIF}_{\mathrm{d}}$ & $-0.35^{*}$ & -0.31 & $-0.73^{* * *}$ & $-0.56^{* * *}$ & $0.79 * * *$ & -0.05 \\
\hline WSAV SIF ${ }_{\mathrm{d}}$ & $-0.40^{*}$ & $0.54^{* * *}$ & $-0.66^{* * *}$ & $-0.55^{* * *}$ & $0.82^{* * *}$ & -0.02 \\
\hline
\end{tabular}


Table 1. Cont.

\begin{tabular}{|c|c|c|c|c|c|c|}
\hline \multicolumn{7}{|c|}{$V P D$} \\
\hline & Amazon & Atlantic Forest & Caatinga & Cerrado & Pampa & Pantanal \\
\hline $\mathrm{DBF} \mathrm{SIF}_{\mathrm{d}}$ & 0.16 & 0.10 & $-0.57^{* * *}$ & $-0.80 * * *$ & $0.59 * *$ & -0.29 \\
\hline EBF SIF $_{d}$ & 0.01 & $0.60^{* * *}$ & $-0.71^{* * *}$ & $-0.69 * *$ & $0.47 * *$ & -0.23 \\
\hline GRA SIF $_{\mathrm{d}}$ & $-0.81^{* * *}$ & -0.19 & $-0.85 * * *$ & $-0.72 * * *$ & $0.74^{* * *}$ & -0.22 \\
\hline SAV SIF $_{d}$ & $-0.60 *$ & 0.03 & $-0.81^{* * *}$ & $-0.79 * * *$ & $0.74^{* * *}$ & -0.24 \\
\hline WSAV SIF & $-0.55^{*}$ & 0.31 & $-0.77^{* * *}$ & $-0.77 * * *$ & $0.78^{* * *}$ & -0.19 \\
\hline
\end{tabular}

\subsection{Seasonality of $\operatorname{SIF}_{d}$}

EBF SIF $_{d}$ has the highest base integrated $\operatorname{SIF}_{d}$ of all vegetation classes in the Amazon as well as in any vegetation class in any other biome $\left(2.6 \mathrm{Wm}^{-2} \mathrm{~nm}^{-1} \mathrm{sr}^{-1}\right.$ Figure 5, panels a-f). Vegetation classes in the Amazon have higher base integrated $\mathrm{SIF}_{\mathrm{d}}$ than their counterparts in other biomes, and generally show that the base integrated $\operatorname{SIF}_{d}$ of the Amazon, in terms of continuously high $\mathrm{SIF}_{d}$, would be higher year-round than other biomes. Base integrated $\mathrm{SIF}_{\mathrm{d}}$ of EBF in the Amazon exceeds all other classes in all other biomes (by 0.33 to $2.27 \mathrm{Wm}^{-2} \mathrm{~nm}^{-1} \mathrm{sr}^{-1}$ ). Base integrated SIF $_{\mathrm{d}}$ for GRA in the Caatinga has the lowest value of any class in any biome at $0.33 \mathrm{Wm}^{-2} \mathrm{~nm}^{-1} \mathrm{sr}^{-1}$ (Figure 5, panel c). The Amazon, Caatinga, Cerrado, and Pantanal GRA base integrated $\operatorname{SIF}_{d}$ was lower than the other than vegetation classes' base integrated $\operatorname{SIF}_{d}$ in each of their respective biomes $(1.29,0.33,0.7,0.83$, and $0.93 \mathrm{Wm}^{-2} \mathrm{~nm}^{-1} \mathrm{sr}^{-1}$, respectively).

The seasonal pulse integrated $\mathrm{SIF}_{\mathrm{d}}$ values are represented as the upper bars (orange) in the stacked bar plot (Figure 5). The largest seasonal pulse $\mathrm{SIF}_{\mathrm{d}}$ is found in the Pantanal for EBF $\left(2.42 \mathrm{Wm}^{-2} \mathrm{~nm}^{-1} \mathrm{sr}^{-1}\right)$. The Pampa SAV and WSAV seasonal pulse integrated SIF $_{d}$ are the next larger seasonal pulse (1.88 and $1.78 \mathrm{Wm}^{-2} \mathrm{~nm}^{-1} \mathrm{sr}^{-1}$, respectively, Figure 5, panels a and e). The smallest seasonal pulses are in the Amazon and Atlantic Forest (Figure 5). Amazon DBF has the smallest seasonal pulse integrated SIF $_{d}$ compared to other vegetation classes within the Amazon and across all other vegetation classes in all biomes $\left(0.18 \mathrm{Wm}^{-2} \mathrm{~nm}^{-1} \mathrm{sr}^{-1}\right)$ (Figure 5, panel a).

The sum of the base and seasonal pulse integrated $\operatorname{SIF}_{d}$ values represent the total seasonal integrated SIF $_{d}$ (Figure 5). Total integrated SIFd of EBF exceeds all other classes in all other biomes by 0.07 to $1.10 \mathrm{Wm}^{-2} \mathrm{~nm}^{-1} \mathrm{sr}^{-1}$. When the total seasonal integrated $\mathrm{SIF}_{\mathrm{d}}$ is considered, the Pantanal EBF integrated $\operatorname{SIF}_{\mathrm{d}}$ has the highest overall value of $3.79 \mathrm{Wm}^{-2} \mathrm{~nm}^{-1} \mathrm{sr}^{-1}$ (Figure 5, panel $\mathrm{f}$ ), followed closely by Amazon EBF at $3.31 \mathrm{Wm}^{-2} \mathrm{~nm}^{-1} \mathrm{sr}^{-1}$ (Figure 5, panel a), compared to all other vegetation classes in all other biomes. EBF total integrated $\mathrm{SIF}_{\mathrm{d}}$ was the highest within each biome compared to all other vegetation classes (2.63-2.79 $\mathrm{Wm}^{-2} \mathrm{~nm}^{-1} \mathrm{sr}^{-1}$, Figure 5, panel a-f). GRA total integrated $\mathrm{SIF}_{\mathrm{d}}$ in the Atlantic Forest has the lowest value of all vegetation classes in all biomes $\left(1.53 \mathrm{Wm}^{-2} \mathrm{~nm}^{-1} \mathrm{sr}^{-1}\right.$, Figure 5 , panel b). Within the biomes, GRA total integrated $\operatorname{SIF}_{\mathrm{d}}$ was lowest in the Amazon $\left(1.76 \mathrm{Wm}^{-2} \mathrm{~nm}^{-1} \mathrm{sr}^{-1}\right.$, Figure 5, panel a), Atlantic Forest, Cerrado (2.05 $\mathrm{Wm}^{-2} \mathrm{~nm}^{-1} \mathrm{sr}^{-1}$, Figure 5, panel d), and Pantanal $\left(2.39 \mathrm{Wm}^{-2} \mathrm{~nm}^{-1} \mathrm{sr}^{-1}\right.$, Figure 5, panel f). SAV total integrated $\mathrm{SIF}_{\mathrm{d}}$ was the lowest value in the Caatinga $\left(1.67 \mathrm{Wm}^{-2} \mathrm{~nm}^{-1} \mathrm{sr}^{-1}\right.$, Figure 5, panel c). 


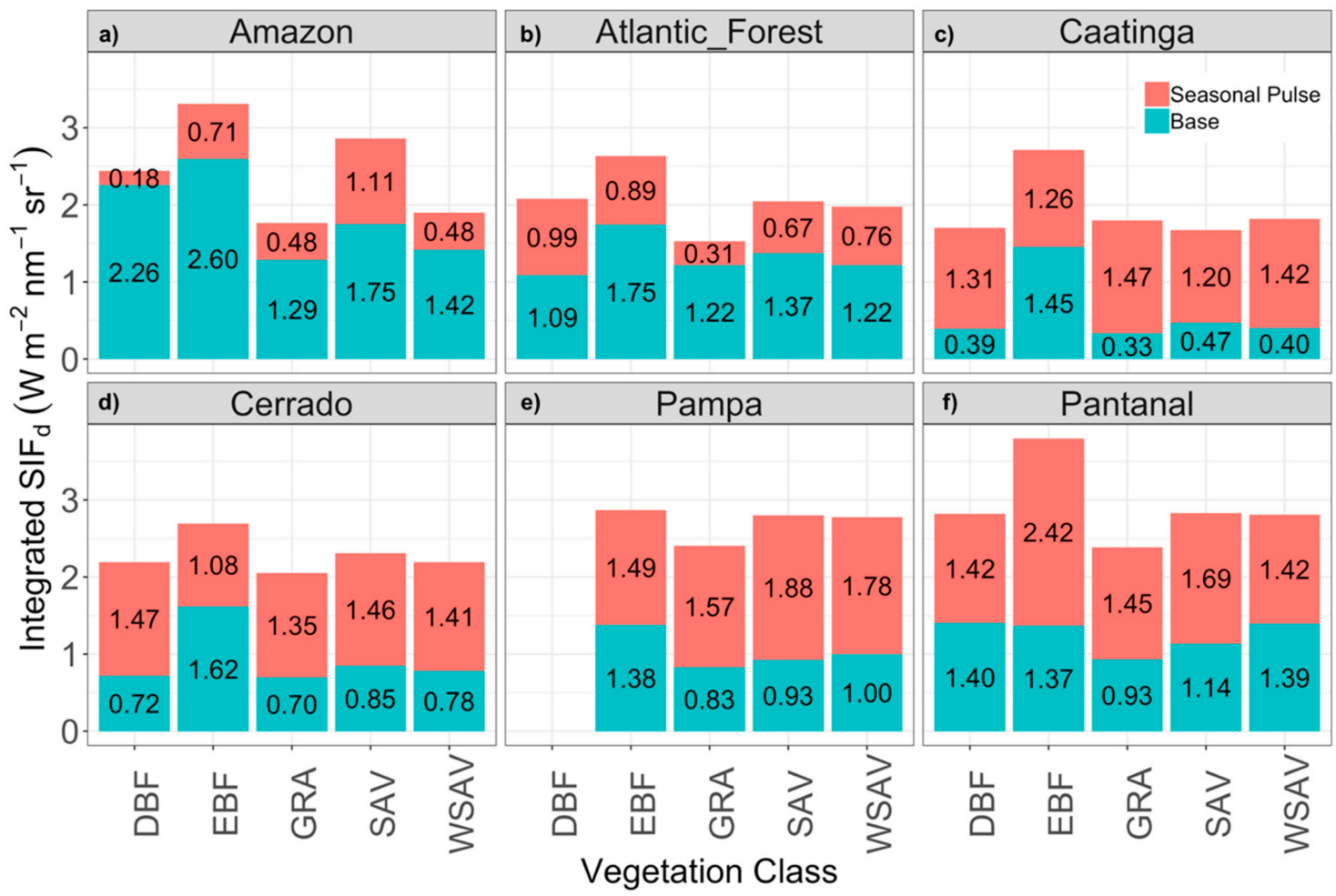

Figure 5. Stacked bar plots of vegetation class-specific per season base (lower bars, blue) and seasonal pulse (upper bars, orange) integrated $\operatorname{SIF}_{\mathrm{d}}$ for the (a) Amazon (b) Atlantic Forest (c) Caatinga (d) Cerrado (e) Pampa and (f) Pantanal. Values for integrated $\mathrm{SIF}_{\mathrm{d}}$ are printed on the corresponding bars.

The length of season (LOS) for each vegetation class in each biome calculated from TIMESAT showed that the values differed for vegetation classes within biomes (Figure S12). For example,

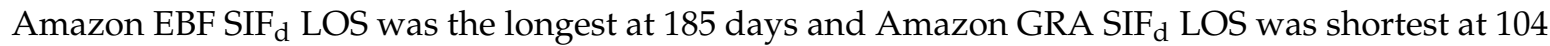
days (Figure S12). Pampa WSAV has the longest calculated SIF $_{d}$ LOS at 2015 days and Atlantic Forest GRA SIF $_{d}$ has the shortest at 99 days (Figure S12). The mean SIF $_{d}$ LOS for a biome (the average of the SIF $_{d}$ LOS of DBF, EBF, GRA, SAV and WSAV within that biome) resulted in: Pantanal (193 days), Cerrado (168 days), Caatinga (167 days), Pampa (157 days), Amazon (145 days), and Atlantic Forest (135 days) (Figure S13). The only significant difference in mean SIF $_{d}$ LOS was between the Pantanal and Pampa $(p<0.05)$, Pantanal and Atlantic Forest $(p<0.01)$, and the Pantanal and Amazon $(p<0.05)$ (Figure S13). A comparison of the $\mathrm{SIF}_{\mathrm{d}}$ LOS of each vegetation class and the total integrated SIF $_{\mathrm{d}}$ for each vegetation class is shown in Figure 6. Our results show that the length of season only explains $30 \%$ of the variation in total integrated $\mathrm{SIF}_{\mathrm{d}}$ (Figure 6; adjusted $\mathrm{R}^{2}=0.30$, intercept $=0.68$, slope $=0.01$, $p<0.01$ ). For every increase of one day in the length of season, on average, there is only a small corresponding increase in total integrated $\mathrm{SIF}_{\mathrm{d}}$ of $0.01 \mathrm{Wm}^{-2} \mathrm{~nm}^{-1} \mathrm{sr}^{-1}$. 


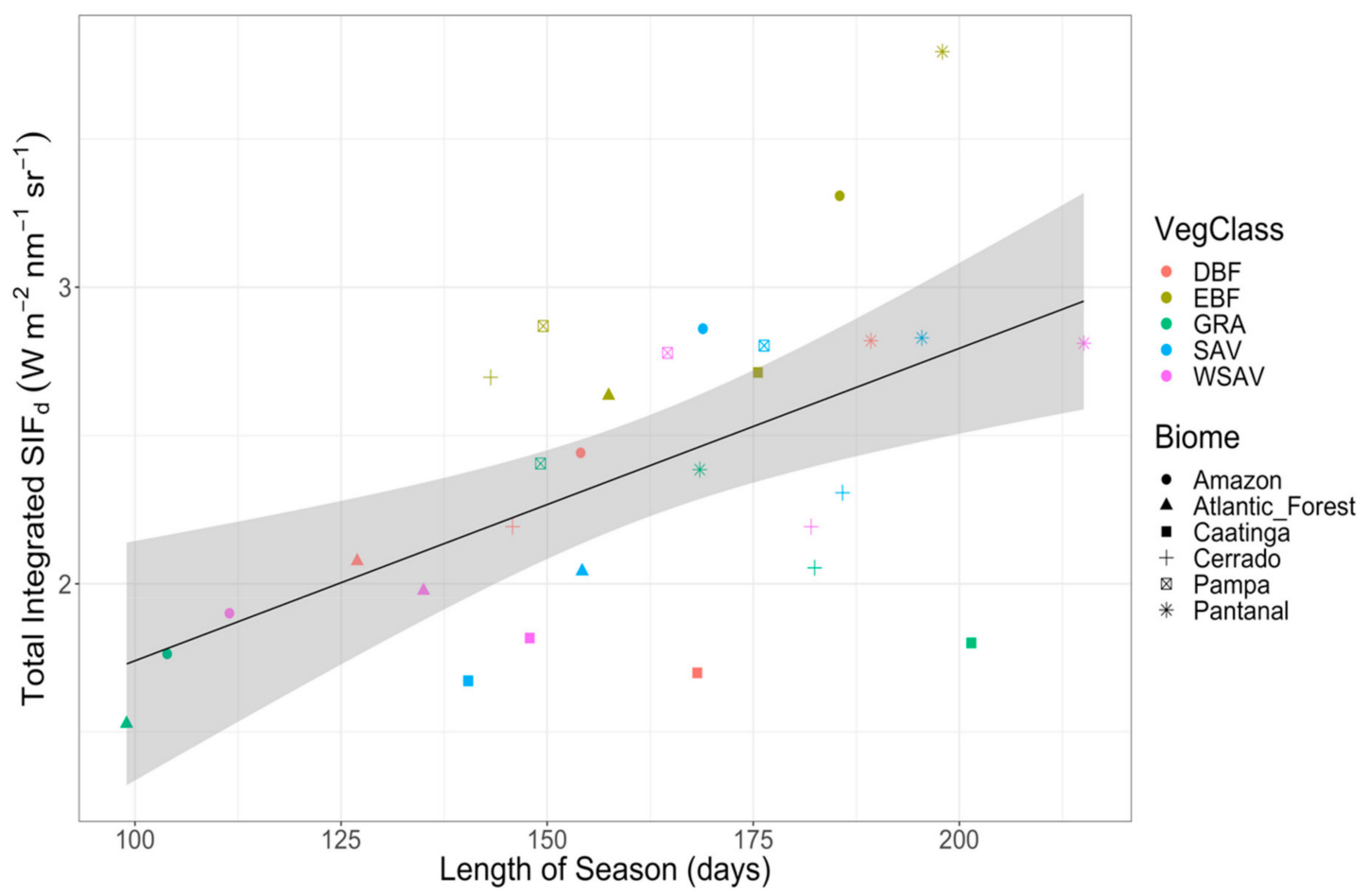

Figure 6. Total integrated $\mathrm{SIF}_{\mathrm{d}}$ versus length of season with generalized linear model represented (black line) and gray region represents $95 \%$ confidence interval (adjusted $R^{2}=0.30$, intercept $=0.68$, slope $=0.01, p<0.01)$.

\section{Discussion}

Here, we compare differences in the mean and seasonal distribution of $\operatorname{SIF}_{\mathrm{d}}$ for the country of Brazil by biome and vegetation classes within biomes. The results of our analyses and significant interaction between vegetation class and biome demonstrates that average values for vegetation classes should consider the biomes in which they occur. Furthermore, average values (Figure 4) do not capture important seasonal dynamics (Figures 5 and 6), which show that high mean values can result from low rates of productivity over a longer period of time or high seasonal pulses that may be brief (Figure 5, Figures S12 and S13).

Through an examination of differences in mean and seasonality of $\mathrm{SIF}_{\mathrm{d}}$ from satellite we were able to construct a more complete picture of vegetation photosynthetic activity of regions in Brazil as captured by OCO-2, a satellite-based instrument. In the Amazon, we found that mean SIF for the biome was highest and variation of $\mathrm{SIF}_{\mathrm{d}}$ lowest of all other biomes, which was not surprising based on our understanding of the effects of biomass and chlorophyll content on vegetation remote sensing measurements. To our knowledge, however, no studies have previously shown these results. Mean EBF SIF ${ }_{d}$ was highest of vegetation classes within the Amazon and highest of EBF SIF in all biomes. Positive correlations between mean GRA, SAV, and WSAV SIF and $\mathrm{T}_{\text {can }}, \mathrm{T}_{\text {air }}$, and VPD were found in the Amazon and the strongest correlations were with VPD, indicating that a higher VPD is correlated with higher $\mathrm{SIF}_{\mathrm{d}}$ for these classes. However, a lack of correlation of DBF and EBF SIF with $\mathrm{T}_{\text {can }}, \mathrm{T}_{\mathrm{air}}$, and VPD may be attributed to the relatively small range of values for $\mathrm{SIF}, \mathrm{T}_{\mathrm{can}}, \mathrm{T}_{\mathrm{air}}$, and VPD for DBF and EBF in the Amazon. Looking at seasonal metrics shows $\mathrm{SIF}_{d}$ seasonal dynamics in the Amazon that are masked by analysis of mean $\mathrm{SIF}_{d}$. Although Amazon EBF had the highest mean $\mathrm{SIF}_{\mathrm{d}}$ than any other vegetation class in all biomes, investigating the seasonality of SIF revealed that the Pantanal had a stronger seasonal pulse of integrated $\mathrm{SIF}_{\mathrm{d}}$, higher total integrated $\mathrm{SIF}_{\mathrm{d}}$ and the longest growing season length. In contrast, Amazon forests remained productive throughout the year (based integrated $\mathrm{SIF}_{\mathrm{d}}$ ) with little seasonality (pulse integrated $\mathrm{SIF}_{\mathrm{d}}$ ). Overall, values for VPD in the Amazon were the lowest of the biomes in the study, just behind the Pampa, and $\mathrm{T}_{\mathrm{can}}$ and $\mathrm{T}_{\text {air }}$ were relatively 
moderate, which indicates the most favorable photosynthetic conditions and is supported by the high rates of base integrated SIF relative to other biomes and higher base integrated SIF $_{d}$ for the Amazon found in the study (Figure 5, Figures S8-S10).

For the Atlantic Forest, mean $\mathrm{SIF}_{\mathrm{d}}$ for the biome was not different from the Cerrado, Pampa, or Pantanal. Mean EBF SIF $\mathrm{d}_{\mathrm{d}}$ was higher than other vegetation classes in the Atlantic Forest and was correlated positively with $\mathrm{T}_{\text {can }}, \mathrm{T}_{\text {air }}$, and $\mathrm{VPD}$, and the strongest of these was with $\mathrm{T}_{\text {air. }}$ While mean WSAV SIF $_{d}$ was not significantly different than SAV and GRA, it had a significant correlation with $\mathrm{T}_{\text {air }}$ most strongly, then with $\mathrm{T}_{\text {can }}$ next, and neither SAV nor GRA were correlated with these climate variables. This suggests that for these classes $\mathrm{T}_{\text {air }}$ is more influential compared to the other biomes. Seasonality analysis showed that EBF had the highest integrated base and total integrated SIF ${ }_{d}, b_{\text {but DBF }}$ had the highest seasonal pulse integrated $\mathrm{SIF}_{\mathrm{d}}$ of the Atlantic Forest vegetation classes. The lack of difference in means and correlations between $\mathrm{SIF}_{\mathrm{d}}$ and environmental variables for some vegetation classes in the Atlantic Forest may have resulted from several factors. First, the range of latitudes spanned by the Atlantic Forest biome is large (approximately $29^{\circ}, \sim-3^{\circ}$ to $-30^{\circ}$ ) having a corresponding large range of changes in solar angles as well as environmental conditions, the altitudinal range is large, and the Atlantic Ocean borders this latitudinal gradient, driving differences in rainfall and vegetation composition [120]. These conditions are expected to have an impact when averaging over space and time to mask trends and relationships [120,141]. Second, the degree of deforestation in the Atlantic Forest original vegetation is over $88 \%$ of the original forest and the remaining forest fragments are small (<50 ha) and isolated [120,142]. This mosaic of highly anthropogenic vegetation would make it difficult to capture the proper vegetation classification at these coarse scales and highlights the possibility that the vegetation classification may need to be improved or at higher resolution to capture vegetation class specific relationships to the environment in future studies. Third, much of the biome has been converted to cropland with asynchronous cycles of harvest and planting and it may be reasonable that croplands erroneously included in the classes examined, especially GRA and SAV, due course resolution or misclassification, would additionally affect the results and mask trends [120,142].

Investigating the biome level mean $\mathrm{SIF}_{\mathrm{d}}$ and mean $\mathrm{SIF}_{\mathrm{d}}$ among vegetation classes in the Caatinga only confirmed expectations, while comparisons to climate variables and analysis of seasonality further elucidated the root behavior of $\mathrm{SIF}_{\mathrm{d}}$ in the Caatinga. Mean $\mathrm{SIF}_{\mathrm{d}}$ of the Caatinga was lowest among all biomes, had the highest variability, and mean SIF $_{d}$ among vegetation classes in the Caatinga had lower magnitudes than their counterparts in other biomes. This was anticipated based on the dry climate and vegetation makeup of dry shrubland, seasonally dry tropical forest, and xeric in contrast to other biomes $[116,117]$. However, correlations of mean SIF to $\mathrm{T}_{\text {can }}, \mathrm{T}_{\mathrm{air}}$, and VPD for the Caatinga were all negative and strongest between mean $\mathrm{SIF}_{d}$ and VPD followed by $\mathrm{T}_{\mathrm{can}}$, just as they were in the Cerrado. This indicates mean $\mathrm{SIF}_{\mathrm{d}}$ responds similarly in these two biomes, but in contrast to the others, potentially related to their similar latitudinal ranges and climate. Seasonality analysis revealed more intricate differences in the Caatinga. Base integrated $\mathrm{SIF}_{\mathrm{d}}$ in the Caatinga for all vegetation classes was lowest of the biomes and seasonal pulse integrated $\mathrm{SIF}_{\mathrm{d}}$ was not lowest, indicating that the base integrated $\mathrm{SIF}_{\mathrm{d}}$ is responsible for the overall lower mean $\mathrm{SIF}_{\mathrm{d}}$ (Figure 5). The lengths of individual vegetation class SIF seasons varied from those of the Cerrado (Figure S12), but the average length of the seasons for SIF in the Caatinga was not different than other biomes and was calculated within one day of the Cerrado (Figure S13). Taken together, these results support findings of previous studies showing that VPD and productivity of grasslands and seasonally dry tropical forest (measured with NDVI) vary widely and that change in climate conditions (VPD) in the wet season correlates with greater productivity [116]. However, the IGBP classification utilized in our study does not allow us to distinguish seasonally dry tropical forest or to match our results in-kind to previous studies. In order to distinguish particular vegetation class productivity behavior in future work, improved classification resolution or alignment of classification with other studies, including a seasonally dry tropical forest, would be an important component to better understand productivity in the Caatinga. 
We found the Cerrado mean $\mathrm{AVC} \mathrm{SIF}_{\mathrm{d}}$ was not different from the Atlantic Forest, Pampa, and Pantanal at the biome level, but was different than the Caatinga and Amazon. Also, analysis of mean $\mathrm{SIF}_{\mathrm{d}}$ among vegetation classes did not further distinguish the Cerrado. However, the Cerrado and Caatinga mean $\mathrm{SIF}_{\mathrm{d}}$ correlations to $\mathrm{T}_{\mathrm{can}}, \mathrm{T}_{\text {air }}$, and VPD were negative and strongest with VPD followed by $\mathrm{T}_{\text {can }}$, in contrast to other biomes, especially the Pampa, where mean SIF $_{d}$ correlations were positive and strongest with $\mathrm{T}_{\text {can }}$. and in contrast to the Pantanal, where no significant correlations of mean $\mathrm{SIF}_{\mathrm{d}}$ with $\mathrm{T}_{\text {can }}, \mathrm{T}_{\mathrm{air}}$, nor VPD occurred (Table 1 ). These results suggest that to capture variation in vegetation function, it is necessary to investigate the individual vegetation class $\operatorname{SIF}_{\mathrm{d}}$ in the context of climate variables because differences in the response of SIF in the Cerrado and Pampa would have been missed without investigating correlations of $\mathrm{SIF}_{\mathrm{d}}$ with $\mathrm{T}_{\mathrm{can}}, \mathrm{T}_{\text {air }}$, and VPD.

The Cerrado was further distinguished from the Atlantic Forest, Pampa, and Pantanal biomes by seasonality analysis of $\operatorname{SIF}_{d}$. In the Cerrado, for instance, base integrated $\operatorname{SIF}_{d}$ is lower for all classes than Atlantic Forest, while total and pulse integrated $\mathrm{SIF}_{\mathrm{d}}$ is higher all vegetation classes. So, year-round SIF $_{d}$ in the Cerrado is less than in the Atlantic forest, but there is a higher degree of seasonality, likely driven by more pronounced cycle of environmental factors in the Cerrado versus the Atlantic Forest. Cerrado EBF base integrated $\operatorname{SIF}_{d}$ exceeds the base integrated $\mathrm{SIF}_{\mathrm{d}}$ in the Pampa and Pantanal, but has a smaller seasonal pulse, while GRA, SAV, and WSAV SIFd in the Cerrado have lower base and seasonal pulses compared to the Pampa and Pantanal. These results indicate that the climate in the Pampa and Pantanal is more favorable to GRA, SAV, and WSAV productivity year-round and seasonally than the Cerrado, but only seasonally for $\mathrm{EBF} \mathrm{SIF}_{\mathrm{d}}$. Thus, productivity of GRA, SAV, and WSAV in the Cerrado is more hindered than in the Pampa or Pantanal, likely due to the climate of the Cerrado being warmer and drier than the Pampa and drier than the Pantanal (Figure 5). In all three biomes, however, the largest values of $\operatorname{SIF}_{d}$ are captured in the EBF classes, consistent with higher biomass as expected. Furthermore, our seasonality analysis indicates the average length of season in the Cerrado is not different than any other biome (within one day of the Caatinga), but differences occur in seasonal and year-round levels of SIF $_{d}$, indicating that OCO-2 SIF captures photosynthetic activity differences. To capture subtler spatiotemporal differences, we suggest it is necessary to investigate more than differences in means based on temporal patterns that would be missed without seasonality analysis.

In the Pampa, there were no differences in mean $\operatorname{SIF}_{d}$ at the biome level with the Atlantic Forest, Cerrado, and Pantanal and analyses of mean differences in SIF among vegetation classes did not reveal any contrasts with the other biomes. However, the Pampa was unique having positive correlations with climate variables compared to other biomes, which likely result from the cooler and more temperate climate (i.e., lower values of $\mathrm{T}_{\mathrm{can}}, \mathrm{T}_{\mathrm{air}}$, and VPD; Figures S2-S4) in the Pampa compared to the other biomes [124]. The stark contrast of $\mathrm{T}_{\text {can }}$ and $\mathrm{T}_{\text {air }}$ ranges in the Pampa (from $286 \mathrm{~K}$ to $311 \mathrm{~K}$ ) to the ranges in the Caatinga and Cerrado (from 297K to 319K) paired with lower VPD values in the Pampa then the Caatinga and Cerrado highlight the contrast in this Brazilian biome. The Pampa grassland dominate the vegetation and its' phytogeography in in contrast to the biomes to its North. It is for these reasons the Pampa was expected to display different behavior, which the satellite-based SIF from OCO-2 was able to capture. It was expected that the seasonality analysis may reveal a more distinct pattern in the Pampa, such as shorter length of seasons, yet, aside from the most uniform lengths of seasons among the vegetation classes (maximum difference in length of seasons $=30$ ), this was not the case in this study. Also unique to the Pampa biome, we showed that $\mathrm{T}_{\text {can }}$ in the Pampa is the most correlated with all vegetation classes' SIF, except DBF. The opposite is true for DBF $\mathrm{SIF}_{d}$, where $\mathrm{T}_{\text {can }}$ is the least correlated, however, the low number of samples of DBF in the Pampa and their lack of representation in the time series consistently make these results less reliable.

Based on mean $\mathrm{SIF}_{\mathrm{d}}$ analysis, the Pantanal would not appear to have clear distinctions from the other biomes. No difference in biome level mean $\operatorname{SIF}_{\mathrm{d}}$ for the Pantanal was found with the Atlantic Forest, Cerrado, and Pampa and, like other biomes mean SIF for EBF in the Pantanal was significantly higher than all other classes in the Pantanal. Yet analyses of mean $\operatorname{SIF}_{d}$ relationships to $\mathrm{T}_{\text {can }}, \mathrm{T}_{\text {air }}$, 
and VPD and seasonality analysis revealed important distinctions in the Pantanal. Unique to the Pantanal, we found no significant correlations with $\mathrm{T}_{\mathrm{can}}, \mathrm{T}_{\mathrm{air}}$, and VPD. This may be indicative of the unique patterns of evapotranspiration in this biome that is a seasonally flooded wetland, whose climate and phytogeographical distribution is unique to Brazil and the world, emphasized by its status as a UNESCO world heritage site $[109,124,143]$. Values of $\mathrm{T}_{\text {can }}, \mathrm{T}_{\text {air }}$ and VPD for the Pantanal reach the highest values of all the biomes in the study, the mean $\operatorname{SIF}_{d}$ length of season is longer than other biomes, and vegetation class total integrated $\mathrm{SIF}_{\mathrm{d}}$ is higher for all classes except SAV in the Pantanal compare to other biomes. Furthermore, seasonality analysis shows that total integrated $\mathrm{SIF}_{\mathrm{d}}$ of $\mathrm{EBF}$

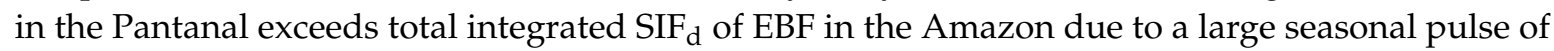
EBF in the Pantanal. The degree to which the total integrated SIF $_{d}$ in the Pantanal exceeded the other biomes' total integrated EBF prompted us to investigate outliers and anomalies carefully, yet none were found with these methods. These results suggest that these unique conditions give rise to vegetation responses we do not yet understand due to a lack of research in this region. To better understand $\mathrm{SIF}_{\mathrm{d}}$, productivity, and the climate influences on $\mathrm{SIF}_{\mathrm{d}}$ in the Pantanal, more detailed climate and SIF $_{\mathrm{d}}$ data are needed. We suggest higher resolution $\mathrm{SIF}_{\mathrm{d}}$ data coupled with vegetation indices, such as the photochemical reflectance index and enhanced vegetation index, measured in conjunction with temperature and precipitation, for instance.

Mean EBF SIF $\mathrm{d}_{\mathrm{d}}$ is significantly higher relative to other classes within each biome highlighting the rate of $\mathrm{SIF}_{\mathrm{d}}$ for EBF is significantly higher in most climatic and geographic regions than its vegetation neighbors (Figure 4). These results are consistent with studies, such as Li et al. (2018), who examined OCO-2 SIF measurements and GPP from flux towers at 64 sites across the globe and found tropical forests had higher SIF in comparison with other vegetation classes [42]. However, the same study showed SIF $_{d}$ in GRA was lower, while, we show mean SIF $_{d}$ of GRA is not significantly different than other vegetation class mean $\mathrm{SIF}_{\mathrm{d}}$ in four biomes (Atlantic Forest, Caatinga, Pampa, Pantanal; Figure 4) and total integrated GRA SIF ${ }_{d}$ in the Caatinga exceeds DBF and SAV total integrated SIF . $_{d}$ We acknowledge, however, their study did not include data from South America and specifically examined locations with flux towers, making it difficult to compare results directly, highlighting the importance of scale and sampling location on results, and emphasizing the need for more multiscale data and research of a variety of tropical vegetation classes [42].

We examined relationships of $\mathrm{SIF}_{\mathrm{d}}$ to $\mathrm{T}_{\mathrm{can}}, \mathrm{T}_{\text {air, }}$ and VPD, to identify potential relationships between $\mathrm{SIF}_{\mathrm{d}}$ and the environment. Temperature is one of the most influential abiotic factors on photosynthesis and GPP, affecting physiological functioning, distribution and range shifts, and competitive success of species e.g., $[4,7,8,13,140,144-148]$. Most research has focused on $\mathrm{T}_{\text {air }}$ to examine the relationships between plant function and temperature, but recent studies have shown that $\mathrm{T}_{\text {air }}$ may not capture thermal properties of vegetation microclimate and environment. $\mathrm{T}_{\mathrm{can}}$ has been shown to differ from $T_{\text {air }}$ in that $T_{\text {can }}$ is generally warmer than Tair and more coupled to water and radiative processes [140,146,149-152]. VPD influences stomatal conductance and, as such is a good metric for water stress conditions, thus lower values of VPD are generally associated with more favorable photosynthetic activity conditions for vegetation. Our results show that most biomes are most strongly related to VPD and then $\mathrm{T}_{\text {can }}$, followed by $\mathrm{T}_{\text {air }}$. These results support recent studies showing that $\mathrm{T}_{\mathrm{can}}$ is potentially more related to photosynthetic function in tropical regions than $T_{\text {air }}$ and serve to provide incentive to further elucidate $\mathrm{SIF}_{\mathrm{d}}$ relationships to these variables [85,153].

We compared total integrated $\mathrm{SIF}_{\mathrm{d}}$ to the length of season and found that the length of season explains only $30 \%$ of the variation in total integrated $\mathrm{SIF}_{\mathrm{d}}$ (Figure 6; Adjusted $\mathrm{R}^{2}=0.30, \mathrm{~m}=0.01$, $p<0.001$ ); therefore, differential physiological functioning (photosynthetic activity) responses of vegetation classes' SIF to environmental factors are potentially more influential on the seasonal levels of $\mathrm{SIF}_{\mathrm{d}}$. This result is an important first step to understanding productivity of multiple tropical vegetation classes.

Our study quantifies relative SIF among vegetation classes within and across biomes. These results are most certainly also related to structure and incoming and radiation and tightly coupled to the 
latitude and elevation of each biome. To test and separate these factors, further study is needed at sub-biome levels fusing satellite SIF data with tower and/or unmanned aerial vehicle data on productivity for better defining the SIF-GPP relationship across scales in the tropics.

\section{Conclusions}

This study demonstrated that important differences in $\mathrm{SIF}_{\mathrm{d}}$ within and across biomes can be captured and quantified with satellite $\mathrm{SIF}_{\mathrm{d}}$ observations from OCO-2. Spatial patterns and variability investigated at biome level through statistical analyses of the observations yielded: (1) EBF SIF in every class had higher integrated SIF than other classes within each biome. (2) The highest mean SIF of EBF occurred in the Amazon. (3) SIF is most strongly correlated with vapor pressure deficit (VPD) for most vegetation classes in most biomes, followed by canopy temperature $\left(T_{\text {can }}\right)$, although the strength and direction of the correlations depend on biome. Phenological analysis examined beyond mean differences determined that: (1) Amazon $\mathrm{SIF}_{\mathrm{d}}$ had the highest year-round values of integrated $\mathrm{SIF}_{\mathrm{d}}$ and the smallest seasonal pulse integrated $\mathrm{SIF}_{d}$; (2) complex patterns of year-round and seasonal SIFd are captured by satellite measurements of SIF. (3) Pantanal EBF had the highest total integrated SIF due to a large seasonal pulse, and (4) the $\mathrm{SIF}_{\mathrm{d}}$ length of season for vegetation classes only explains $30 \%$ of the variation in total integrated $\mathrm{SIF}_{\mathrm{d}}$; thus, the length of season is probably more closely tied to leafing patterns and leaf area, whereas integrated $\operatorname{SIF}_{\mathrm{d}}$ captures variations in photosynthetic activity separate from structural differences. In other words, SIF and traditionally used vegetation indices may similarly define the length of seasons (vegetation indices and SIF both increase with leaf area increases), but peak season responses where traditional vegetation indices tend to saturate, are being better captured by SIF. To our knowledge, no studies have examined OCO-2 data for a comparison of vegetation class-specific SIF or phenology in the tropics. Because SIF is more mechanistically coupled to photosynthetic activity than more commonly used vegetation indices in remote sensing studies of ecosystem dynamics, our results provide novel satellite estimates of differences in productivity across biomes and vegetation types and these measurements quantify differences in SIF in continuous units $\left(\mathrm{Wm}^{-2} \mathrm{~nm}^{-1} \mathrm{sr}^{-1}\right)$, also in contrast to vegetation indices.

Supplementary Materials: The following are available online at http://www.mdpi.com/2072-4292/11/15/1746/s1, Table S1. List of abbreviations and variables used. Table S2. IGBP classification and descriptions. Table S3. Table of values for the distribution of SIF observations by biome and vegetation class: number of footprints, area, and percent of biome and percent of Brazil. Table S4. Vegetation class-specific mean SIF $_{\mathrm{d}}$ for each biome. Table S5. $p$-values of Tukey's HSD Test for differences in Biome level SIF $\mathrm{d}_{\mathrm{d}}$ (AVC) across Brazilian Biomes. $p$-values below significance level of 0.05 are highlighted. Table S6. $p$-values of Tukey's HSD Test Test for differences in vegetation class-specific SIF $_{\mathrm{d}}$ across Brazilian Biomes. $p$-values below significance level of 0.05 are highlighted. Table S2. List of abbreviations and variables used. Figure S1. Plots of residuals for all OCO-2 SIF data examination for normality. L to R: Residuals vs. Fitted, q-q plot, histogram of residuals. Figure S2. Plots of residuals for Amazon biome OCO-2 SIF data examination for normality. L to R: Residuals vs. Fitted, q-q plot, histogram of residuals. Figure S3. Plots of residuals for Atlantic Forest biome OCO-2 SIF data examination for normality. L to R: Residuals vs. Fitted, q-q plot, histogram of residuals. Figure S4. Plots of residuals for Caatinga biome OCO-2 SIF data examination for normality. L to R: Residuals vs. Fitted, q-q plot, histogram of residuals. Figure S5. Plots of residuals for Cerrado biome OCO-2 SIF data examination for normality. L to R: Residuals vs. Fitted, q-q plot, histogram of residuals. Figure S6. Plots of residuals for Pampa biome OCO-2 SIF data examination for normality. L to R: Residuals vs. Fitted, q-q plot, histogram of residuals. Figure S7. Plots of residuals for Pantanal biome OCO-2 SIF data examination for normality. L to R: Residuals vs. Fitted, q-q plot, histogram of residuals. Figure S8. Scatterplots of $\mathrm{SIF}_{\mathrm{d}}$ vs. Tcan for each vegetation class (indicated in each row) in each biome (indicated in each column). Figure S9. Scatterplots of SIF $_{d}$ vs. $_{\text {air }}$ for each vegetation class (indicated in each row) in each biome (indicated in each column). Figure S10. Scatterplots of SIF $_{d}$ vs. VPD for each vegetation class (indicated in each row) in each biome (indicated in each column). Figure S11. Time series of SIFd for vegetation classes in each biome. Rows correspond to biome: top to bottom-Amazon, Atlantic Forest, Caatinga, Cerrado, Pampa, Pantanal. Columns correspond to vegetation class: Left to Right-DBF, EBF, GRA, SAV, WSAV. Solid lines indicate raw data and dashed lines indicate smoothed data (Moving Average, window $=3$ ). Figure S12. Bar plots of SIF length of season of vegetation classes within biomes for the a) Amazon b) Atlantic Forest c) Caatinga d) Cerrado e) Pampa and f) Pantanal. Values for integrated $\mathrm{SIF}_{\mathrm{d}}$ are printed on the corresponding bars. Figure S13. Boxplots of length of season $\mathrm{SIF}_{\mathrm{d}}$ for biomes a) Amazon b) Atlantic Forest c) Caatinga d) Cerrado e) Pampa and f) Pantanal. Horizontal bars with corresponding $p$-values indicate significance: ${ }^{* * *}=p<0.001,{ }^{* *}=p<0.01,{ }^{*}=p<0.05$, NS $>$ $=$ no significant difference in mean. Boxes represent minimum, 1st quartile, median, 3rd quartile, and maximum values, and the mean value is printed vertically to the left of each box. 
Author Contributions: Conceptualization, T.M., R.B., S.P., M.L.S.P.J., T.S.F.S.; methodology, T.M., R.B., S.P., M.L.S.P.J., T.S.F.S.; data curation and analysis T.M., R.B., S.P., M.L.S.P.J., T.S.F.S.; writing—original draft preparation, T.M.; writing—review and editing, T.M., R.B., S.P., M.L.S.P.J., T.S.F.S.

Funding: This research was funded a partnership between the São Paulo Research Foundation (Fundação de Amparo A Pesquisa do Estado de São Paulo, FAPESP) and Vanderbilt University.

Acknowledgments: We acknowledge the support of the FAPESP partnership between Vanderbilt University, Nashville, TN, USA and Universidade Estadual Paulista (UNESP), Rio Claro, Brazil. This research was possible due to the long-term collaboration among the professors and students at the aforementioned universities.

Conflicts of Interest: The authors declare no conflict of interest.

\section{References}

1. Malhi, Y. The productivity, metabolism and carbon cycle of tropical forest vegetation. J. Ecol. 2012, 100, 65-75. [CrossRef]

2. Wright, S.J. The future of tropical forests. Ann. N. Y. Acad. Sci. 2010, 1195, 1-27. [CrossRef] [PubMed]

3. Sassan, S.S.; Harris, N.L.; Brown, S.; Lefsky, M.; Mitchard, E.T.A.; Salas, W.; Zutta, B.R.; Buerman, W.; Lewis, S.L.; Hagen, S.; et al. Benchmark map of forest carbon stocks in tropical regions across three continents. Proc. Natl. Acad. Sci. USA 2011, 108, 9899-9905.

4. Wright, S.J.; Muller-Landau, H.C.; Schipper, J. The future of tropical species on a warmer planet. Conserv. Biol. 2009, 23, 1418-1426. [CrossRef] [PubMed]

5. Beer, C.; Reichstein, M.; Tomelleri, E.; Ciais, P.; Jung, M.; Carvalhais, N.; Rödenbeck, C.; Arain, M.A.; Baldocchi, D.; Bonan, G.B.; et al. Terrestrial Gross Carbon Dioxide Uptake: Global Distribution and Covariation with Climate. Science 2010, 329, 834-840. [CrossRef]

6. Huntingford, C.; Zelazowski, P.; Galbraith, D.; Mercado, L.M.; Sitch, S.; Fisher, R.; Lomas, M.; Walker, A.P.; Jones, C.D.; Booth, B.B.B.; et al. Simulated resilience of tropical rainforests to $\mathrm{CO}_{2}$-induced climate change. Nat. Geosci. 2013, 6, 268-273. [CrossRef]

7. Clark, D.A.; Asao, S.; Fisher, R.; Reed, S.; Reich, P.B.; Ryan, M.G.; Wood, T.E.; Yang, X. Reviews and syntheses: Field data to benchmark the carbon cycle models for tropical forests. Biogeosciences 2017, 14, 4663-4690. [CrossRef]

8. Clark, D.A.; Piper, S.C.; Keeling, C.D.; Clark, D.B. Tropical rain forest tree growth and atmospheric carbon dynamics linked to interannual temperature variation during 1984-2000. Proc. Natl. Acad. Sci. USA 2003, 100, 5852-5858. [CrossRef]

9. Joiner, J.; Yoshida, Y.; Vasilkov, A.P.; Schaefer, K.; Jung, M.; Guanter, L.; Zhang, Y.; Garrity, S.; Middleton, E.M.; Huemmrich, K.F.; et al. The seasonal cycle of satellite chlorophyll fluorescence observations and its relationship to vegetation phenology and ecosystem atmosphere carbon exchange. Remote Sens. Environ. 2014, 152, 375-391. [CrossRef]

10. Schimel, D.; Pavlick, R.; Fisher, J.B.; Asner, G.P.; Saatchi, S.; Townsend, P.; Miller, C.; Frankenberg, C.; Hibbard, K.; Cox, P. Observing terrestrial ecosystems and the carbon cycle from space. Glob. Chang. Biol. 2015, 21, 1762-1776. [CrossRef]

11. Rossini, M.; Nedbal, L.; Guanter, L.; Ač, A.; Alonso, L.; Burkart, A.; Cogliati, S.; Colombo, R.; Damm, A.; Drusch, M.; et al. Red and far-red sun-induced chlorophyll fluorescence as a measure of plant photosynthesis. Geophys. Res. Lett. 2015, 1632-1639. [CrossRef]

12. Guanter, L.; Zhang, Y.; Jung, M.; Joiner, J.; Voigt, M.; Berry, J.A.; Frankenberg, C.; Huete, A.R.; Zarco-Tejada, P.; Lee, J.E.; et al. Global and time-resolved monitoring of crop photosynthesis with chlorophyll fluorescence. Proc. Natl. Acad. Sci. USA 2014, 111, E1327-E1333. [CrossRef] [PubMed]

13. Porcar-Castell, A.; Tyystjarvi, E.; Atherton, J.; van der Tol, C.; Flexas, J.; Pfundel, E.E.; Moreno, J.; Frankenberg, C.; Berry, J.A. Linking chlorophyll a fluorescence to photosynthesis for remote sensing applications: Mechanisms and challenges. J. Exp. Bot. 2014, 65, 4065-4095. [CrossRef] [PubMed]

14. Frankenberg, C.; Fisher, J.B.; Worden, J.R.; Badgley, G.; Saatchi, S.S.; Lee, J.E.; Toon, G.C.; Butz, A.; Jung, M.; Kuze, A.; et al. New global observations of the terrestrial carbon cycle from GOSAT: Patterns of plant fluorescence with gross primary productivity. Geophys. Res. Lett. 2011, 38. [CrossRef] 
15. Sun, Y.; Frankenberg, C.; Jung, M.; Joiner, J.; Guanter, L.; Köhler, P.; Magney, T.S. Overview of Solar-Induced chlorophyll Fluorescence (SIF) from the Orbiting Carbon Observatory-2: Retrieval, cross-mission comparison, and global monitoring for GPP. Remote Sens. Environ. 2018, 808-823. [CrossRef]

16. Joiner, J.; Yoshida, Y.; Vasilkov, A.P.; Yoshida, Y.; Corp, L.A.; Middleton, E.M. First observations of global and seasonal terrestrial chlorophyll fluorescence from space. Biogeosciences 2011, 8, 637-651. [CrossRef]

17. Duveiller, G.; Cescatti, A. Spatially downscaling sun-induced chlorophyll fluorescence leads to an improved temporal correlation with gross primary productivity. Remote Sens. Environ. 2016, 182, 72-89. [CrossRef]

18. Frankenberg, C. Retrieval of chlorophyll fluorescence from space. In Proceedings of the KISS Fluorescence Workshop, Jet Propulsion Laboratory/California Institute of Technology, Pasadena, CA, USA, 26-31 August 2012; pp. 1-5.

19. Meroni, M.; Rossini, M.; Guanter, L.; Alonso, L.; Rascher, U.; Colombo, R.; Moreno, J. Remote sensing of solar-induced chlorophyll fluorescence: Review of methods and applications. Remote Sens. Environ. 2009, 113, 2037-2051. [CrossRef]

20. Meroni, M.; Panigada, C.; Rossini, M.; Picchi, V.; Cogliati, S.; Colombo, R. Using optical remote sensing techniques to track the development of ozone-induced stress. Environ. Pollut. 2009, 157, 1413-1420. [CrossRef]

21. Guanter, L.; Frankenberg, C.; Dudhia, A.; Lewis, P.E.; Gómez-Dans, J.; Kuze, A.; Suto, H.; Grainger, R.G. Retrieval and global assessment of terrestrial chlorophyll fluorescence from GOSAT space measurements. Remote Sens. Environ. 2012, 121, 236-251. [CrossRef]

22. Parazoo, N.C.; Bowman, K.; Frankenberg, C.; Lee, J.-E.; Fisher, J.B.; Worden, J.; Jones, D.B.A.; Berry, J.; Collatz, G.J.; Baker, I.T.; et al. Interpreting seasonal changes in the carbon balance of southern Amazonia using measurements of XCO2and chlorophyll fluorescence from GOSAT. Geophys. Res. Lett. 2013, 40, 2829-2833. [CrossRef]

23. Wood, J.D.; Griffis, T.J.; Baker, J.M.; Frankenberg, C.; Verma, M.; Yuen, K. Multiscale analyses of solar-induced florescence and gross primary production. Geophys. Res. Lett. 2017, 44, 533-541. [CrossRef]

24. Wieneke, S.; Burkart, A.; Cendrero-Mateo, M.P.; Julitta, T.; Rossini, M.; Schickling, A.; Schmidt, M.; Rascher, U. Linking photosynthesis and sun-induced fluorescence at sub-daily to seasonal scales. Remote Sens. Environ. 2018, 219, 247-258. [CrossRef]

25. Wieneke, S.; Ahrends, H.; Damm, A.; Pinto, F.; Stadler, A.; Rossini, M.; Rascher, U. Airborne based spectroscopy of red and far-red sun-induced chlorophyll fluorescence: Implications for improved estimates of gross primary productivity. Remote Sens. Environ. 2016, 654-667. [CrossRef]

26. Damm, A.; Guanter, L.; Verhoef, W.; Schläpfer, D.; Garbari, S.; Schaepman, M.E. Impact of varying irradiance on vegetation indices and chlorophyll fluorescence derived from spectroscopy data. Remote Sens. Environ. 2015, 156, 202-215. [CrossRef]

27. Sun, Y.; Frankenberg, C.; Wood, J.D.; Schimel, D.S.; Jung, M.; Guanter, L.; Drewry, D.T.; Verma, M.; Porcar-Castell, A.; Griffis, T.J.; et al. OCO-2 advances photosynthesis observation from space via solar-induced chlorophyll fluorescence. Science 2017, 358, 5747. [CrossRef]

28. Verma, M.; Schimel, D.S.; Evans, B.; Frankenberg, C.; Beringer, J.; Drewry, D.T.; Magney, T.S.; Marang, I.; Hutley, L.; Moore, C.; et al. Effect of environmental conditions on the relationship between solar-induced fluorescence and gross primary productivity at an OzFlux grassland site. J. Geophys. Res. Biogeosci. 2017, 122, 1-18. [CrossRef]

29. Wagle, P.; Zhang, Y.; Jin, C.; Xiao, X. Comparison of solar-induced chlorophyll fluorescence, light-use efficiency, and process-based GPP models in maize. Ecol. Appl. 2016, 26, 1211-1222. [CrossRef]

30. Chen, X.; Mo, X.; Hu, S.; Liu, S. Relationship between fluorescence yield and photochemical yield under water stress and intermediate light conditions. J. Exp. Bot. 2019, 70, 301-313. [CrossRef]

31. Guan, K.; Berry, J.A.; Zhang, Y.; Joiner, J.; Guanter, L.; Badgley, G.; Lobell, D.B. Improving the monitoring of crop productivity using spaceborne solar-induced fluorescence. Glob. Chang. Biol. 2016, 22, 716-726. [CrossRef]

32. Panigada, C.; Rossini, M.; Meroni, M.; Cilia, C.; Busetto, L.; Amaducci, S.; Boschetti, M.; Cogliati, S.; Picchi, V.; Pinto, F.; et al. Fluorescence, PRI and canopy temperature for water stress detection in cereal crops. Int. J. Appl. Earth Obs. Geoinf. 2014, 30, 167-178. [CrossRef]

33. Moreno, J.; Moran, S. Vegetation stress from soil moisture and chlorophyll fluorescence: Synergy between SMAP and FLEX approaches. In Proceedings of the EGU General Assembly Conference Abstracts, Vienna, Austria, 27 April-2 May 2014; p. 10574. 
34. Van Wittenberghe, S.; Alonso, L.; Verrelst, J.; Hermans, I.; Delegido, J.; Veroustraete, F.; Valcke, R.; Moreno, J.; Samson, R. Upward and downward solar-induced chlorophyll fluorescence yield indices of four tree species as indicators of traffic pollution in Valencia. Environ. Pollut. 2013, 173, 29-37. [CrossRef] [PubMed]

35. Lee, J.E.; Frankenberg, C.; van der Tol, C.; Berry, J.A.; Guanter, L.; Boyce, C.K.; Fisher, J.B.; Morrow, E.; Worden, J.R.; Asefi, S.; et al. Forest productivity and water stress in Amazonia: Observations from GOSAT chlorophyll fluorescence. Proc. Biol. Sci. R. Soc. 2013, 280, 20130171. [CrossRef] [PubMed]

36. Zarco-Tejada, P.J.; González-Dugo, V.; Berni, J.A.J. Fluorescence, temperature and narrow-band indices acquired from a UAV platform for water stress detection using a micro-hyperspectral imager and a thermal camera. Remote Sens. Environ. 2012, 117, 322-337. [CrossRef]

37. Zarco-Tejada, P.J.; Berni, J.A.J.; Suárez, L.; Sepulcre-Cantó, G.; Morales, F.; Miller, J.R. Imaging chlorophyll fluorescence with an airborne narrow-band multispectral camera for vegetation stress detection. Remote Sens. Environ. 2009, 113, 1262-1275. [CrossRef]

38. Migliavacca, M.; Perez-Priego, O.; Rossini, M.; El-Madany, T.S.; Moreno, G.; van der Tol, C.; Rascher, U.; Berninger, A.; Bessenbacher, V.; Burkart, A.; et al. Plant functional traits and canopy structure control the relationship between photosynthetic $\mathrm{CO} 2$ uptake and far-red sun-induced fluorescence in a Mediterranean grassland under different nutrient availability. New Phytol. 2017, 1078-1091. [CrossRef] [PubMed]

39. Yang, X.; Tang, J.; Mustard, J.F.; Lee, J.E.; Rossini, M.; Joiner, J.; Munger, J.W.; Kornfeld, A.; Richardson, A.D. Solar-induced chlorophyll fluorescence that correlates with canopy photosynthesis on diurnal and seasonal scales in a temperate deciduous forest. Geophys. Res. Lett. 2015, 2977-2987. [CrossRef]

40. Walther, S.; Voigt, M.; Thum, T.; Gonsamo, A.; Zhang, Y.; Koehler, P.; Jung, M.; Varlagin, A.; Guanter, L. Satellite chlorophyll fluorescence measurements reveal large-scale decoupling of photosynthesis and greenness dynamics in boreal evergreen forests. Glob. Chang. Biol. 2015, 2979-2996. [CrossRef]

41. Li, X.; Xiao, J.; He, B. Higher absorbed solar radiation partly offset the negative effects of water stress on the photosynthesis of Amazon forests during the 2015 drought. Environ. Res. Lett. 2018, 044005. [CrossRef]

42. Li, X.; Xiao, J.; He, B.; Altaf Arain, A.M.; Beringer, J.; Desai, A.R.; Emmel, C.; Hollinger, D.Y.; Krasnova, A.; Mammarella, I.; et al. Solar-induced chlorophyll fluorescence is strongly correlated with terrestrial photosynthesis for a wide variety of biomes: First global analysis based on OCO-2 and flux tower observations. Glob. Chang. Biol. 2018, 3990-4008. [CrossRef]

43. Zarco-Tejada, P.J.; Morales, A.; Testi, L.; Villalobos, F.J. Spatio-temporal patterns of chlorophyll fluorescence and physiological and structural indices acquired from hyperspectral imagery as compared with carbon fluxes measured with eddy covariance. Remote Sens. Environ. 2013, 133, 102-115. [CrossRef]

44. Frankenberg, C.; O’Dell, C.; Berry, J.; Joiner, J.; Köhler, P.; Pollock, R.; Taylor, T.E. Prospects for chlorophyll fluorescence remote sensing from the Orbiting Carbon Observatory-2. Remote Sens. Environ. 2014, 147, 1-12. [CrossRef]

45. Damm, A.; Elbers, J.; Erler, A.; Gioli, B.; Hamdi, K.; Hutjes, R.; Kosvancova, M.; Meroni, M.; Miglietta, F.; Moersch, A.; et al. Remote sensing of sun-induced fluorescence to improve modeling of diurnal courses of gross primary production (GPP). Glob. Chang. Biol. 2010, 16, 171-186. [CrossRef]

46. Cox, P.M.; Pearson, D.; Booth, B.B.; Friedlingstein, P.; Huntingford, C.; Jones, C.D.; Luke, C.M. Sensitivity of tropical carbon to climate change constrained by carbon dioxide variability. Nature 2013, 494, 341-344. [CrossRef] [PubMed]

47. Xu, L.; Saatchi, S.S.; Yang, Y.; Myneni, R.B.; Frankenberg, C.; Chowdhury, D.; Bi, J. Satellite observation of tropical forest seasonality: Spatial patterns of carbon exchange in Amazonia. Environ. Res. Lett. 2015, 10, 084005. [CrossRef]

48. Xiao, X.; Hagen, S.; Zhang, Q.; Keller, M.; Moore, B. Detecting leaf phenology of seasonally moist tropical forests in South America with multi-temporal MODIS images. Remote Sens. Environ. 2006, 103, 465-473. [CrossRef]

49. Jones, M.O.; Kimball, J.S.; Nemani, R.R. Asynchronous Amazon forest canopy phenology indicates adaptation to both water and light availability. Environ. Res. Lett. 2014, 9, 124021. [CrossRef]

50. Ma, J.; Xiao, X.; Zhang, Y.; Doughty, R.; Chen, B.; Zhao, B. Spatial-temporal consistency between gross primary productivity and solar-induced chlorophyll fluorescence of vegetation in China during 2007-2014. Sci. Total Environ. 2018, 639, 1241-1253. [CrossRef]

51. Lu, X.; Cheng, X.; Li, X.; Chen, J.; Sun, M.; Ji, M.; He, H.; Wang, S.; Li, S.; Tang, J. Seasonal patterns of canopy photosynthesis captured by remotely sensed sun-induced fluorescence and vegetation indexes in mid-to-high latitude forests: A cross-platform comparison. Sci. Total Environ. 2018, 644, 439-451. [CrossRef] 
52. Springer, K.; Wang, R.; Gamon, J.A. Parallel Seasonal Patterns of Photosynthesis, Fluorescence, and Reflectance Indices in Boreal Trees. Remote Sens. 2017, 9, 691. [CrossRef]

53. Yang, H.; Yang, X.; Zhang, Y.; Heskel, M.A.; Lu, X.; Munger, J.W.; Sun, S.; Tang, J. Chlorophyll fluorescence tracks seasonal variations of photosynthesis from leaf to canopy in a temperate forest. Glob. Chang. Biol. 2017, 23, 2874-2886. [CrossRef] [PubMed]

54. Zarco-Tejada, P.J.; González-Dugo, M.V.; Fereres, E. Seasonal stability of chlorophyll fluorescence quantified from airborne hyperspectral imagery as an indicator of net photosynthesis in the context of precision agriculture. Remote Sens. Environ. 2016, 179, 89-103. [CrossRef]

55. Jeong, S.-J.; Ho, C.-H.; Gim, H.-J.; Brown, M.E. Phenology shifts at start vs. end of growing season in temperate vegetation over the Northern Hemisphere for the period 1982-2008. Glob. Chang. Biol. 2011, 17, 2385-2399. [CrossRef]

56. Zhang, X.; Friedl, M.A.; Schaaf, C.B.; Strahler, A.H.; Hodges, J.C.F. Monitoring vegetation phenology using MODIS. Remote Sens. Environ. 2003, 84, 471-476. [CrossRef]

57. Gu, L.; Baldocci, D.D.; Wofsy, S.C.; Munger, J.W.; Michalsky, J.J.; Urbanski, S.P.; Boden, T.A. Response of a Deciduous Forest to the Mount Pinatubo Eruption: Enhanced Photosynthesis. Science 2003, 299, 2035-2038. [CrossRef] [PubMed]

58. Wright, S.J.; Calderón, O.; Muller-Landau, H.C. A phenology model for tropical species that flower multiple times each year. Ecol. Res. 2019, 34, 20-29. [CrossRef]

59. Wu, C.; Gonsamo, A.; Gough, C.M.; Chen, J.M.; Xu, S. Modeling growing season phenology in North American forests using seasonal mean vegetation indices from MODIS. Remote Sens. Environ. 2014, 147, 79-88. [CrossRef]

60. Yang, J.; Tian, H.; Pan, S.; Chen, G.; Zhang, B.; Dangal, S. Amazon droughts and forest responses: Largely reduced forest photosynthesis but slightly increased canopy greenness during the extreme drought of 2015/2016. Glob. Chang. Biol. 2018, 1919-1934. [CrossRef]

61. Guan, K.; Pan, M.; Li, H.; Wolf, A.; Wu, J.; Medvigy, D.; Caylor, K.K.; Sheffield, J.; Wood, E.F.; Malhi, Y.; et al. Photosynthetic seasonality of global tropical forests constrained by hydroclimate. Nat. Geosci. 2015, 8, 284-289. [CrossRef]

62. Lewis, S.L. Tropical forests and the changing earth system. Philos. Trans. R. Soc. Lond. Ser. B Biol. Sci. 2006, 361, 195-210. [CrossRef]

63. Huete, A.R.; Didan, K.; Shimabukuro, Y.E.; Ratana, P.; Saleska, S.R.; Hutyra, L.R.; Yang, W.; Nemani, R.R.; Myneni, R. Amazon rainforests green-up with sunlight in dry season. Geophys. Res. Lett. 2006, 33. [CrossRef]

64. Samanta, A.; Knyazikhin, Y.; Xu, L.; Dickinson, R.E.; Fu, R.; Costa, M.H.; Saatchi, S.S.; Nemani, R.R.; Myneni, R.B. Seasonal changes in leaf area of Amazon forests from leaf flushing and abscission. J. Geophys. Res. Biogeosci. 2012, 117. [CrossRef]

65. Myneni, R.B.; Yang, W.; Nemani, R.R.; Huete, A.R.; Dickinson, R.E.; Knyazikhin, Y.; Didan, K.; Fu, R.; Negron Juarez, R.I.; Saatchi, S.S.; et al. Large seasonal swings in leaf area of Amazon rainforests. Proc. Natl. Acad. Sci. USA 2007, 104, 4820-4823. [CrossRef] [PubMed]

66. Morton, D.C.; Rubio, J.; Cook, B.D.; Gastellu-Etchegorry, J.P.; Longo, M.; Choi, H.; Hunter, M.O.; Keller, M. Amazon forest structure generates diurnal and seasonal variability in light utilization. Biogeosci. Discuss. 2015, 12, 19043-19072. [CrossRef]

67. Morton, D.C.; Nagol, J.; Carabajal, C.C.; Rosette, J.; Palace, M.; Cook, B.D.; Vermote, E.F.; Harding, D.J.; North, P.R. Amazon forests maintain consistent canopy structure and greenness during the dry season. Nature 2014, 506, 221-224. [CrossRef] [PubMed]

68. Samanta, A.; Ganguly, S.; Vermote, E.; Nemani, R.R.; Myneni, R.B. Why Is Remote Sensing of Amazon Forest Greenness So Challenging? Earth Interact. 2012, 16, 1-14. [CrossRef]

69. Quentin, G.R. Interactions of Vegetation and Climate: Remote Observations, Earth System Models, and the Amazon For; University of Washington: Seattle, WA, USA, 2018.

70. Li, X.; Xiao, J.; He, B. Chlorophyll fluorescence observed by OCO-2 is strongly related to gross primary productivity estimated from flux towers in temperate forests. Remote Sens. Environ. 2018, 204, 659-671. [CrossRef]

71. Liu, L.; Liu, X.; Hu, J. Effects of spectral resolution and SNR on the vegetation solar-induced fluorescence retrieval using FLD-based methods at canopy level. Eur. J. Remote Sens. 2015, 48, 742-761. [CrossRef] 
72. Sims, D.; Rahman, A.; Cordova, V.; Elmasri, B.; Baldocchi, D.; Bolstad, P.; Flanagan, L.; Goldstein, A.; Hollinger, D.; Misson, L. A new model of gross primary productivity for North American ecosystems based solely on the enhanced vegetation index and land surface temperature from MODIS. Remote Sens. Environ. 2008, 112, 1633-1646. [CrossRef]

73. Heinsch, F.A.; Maosheng, Z.; Running, S.W.; Kimball, J.S.; Nemani, R.R.; Davis, K.J.; Bolstad, P.V.; Cook, B.D.; Desai, A.R.; Ricciuto, D.M.; et al. Evaluation of remote sensing based terrestrial productivity from MODIS using regional tower eddy flux network observations. IEEE Trans. Geosci. Remote Sens. 2006, 44, 1908-1925. [CrossRef]

74. Running, S.W.; Zhao, M.Z. User's Guide Daily GPP and Annual NPP (MOD17A2/A3) Products NASA Earth Observing System MODIS Land Algorithm. Available online: https://bit.ly/2Zai7qo (accessed on 23 July 2019).

75. MODIS-Derived Terrestrial Primary Production. Available online: https://link.springer.com/chapter/10.1007/ 978-1-4419-6749-7_28 (accessed on 23 July 2019).

76. Running, S.W.; Nemani, R.R.; Heinsch, F.A.; Zhao, M.; Reeves, M.; Hashimoto, H. A Continuous Satellite-Derived Measure of Global Terrestrial Primary Production. BioScience 2004, 54, 547-551. [CrossRef]

77. Wu, J.; Guan, K.; Hayek, M.; Restrepo-Coupe, N.; Wiedemann, K.T.; Xu, X.; Wehr, R.; Christoffersen, B.O.; Miao, G.; da Silva, R.; et al. Partitioning controls on Amazon forest photosynthesis between environmental and biotic factors at hourly to interannual timescales. Glob. Chang. Biol. 2017, 23, 1240-1257. [CrossRef] [PubMed]

78. Paul-Limoges, E.; Damm, A.; Hueni, A.; Liebisch, F.; Eugster, W.; Schaepman, M.E.; Buchmann, N. Effect of environmental conditions on sun-induced fluorescence in a mixed forest and a cropland. Remote Sens. Environ. 2018, 219, 310-323. [CrossRef]

79. Atherton, J.; Nichol, C.J.; Porcar-Castell, A. Using spectral chlorophyll fluorescence and the photochemical reflectance index to predict physiological dynamics. Remote Sens. Environ. 2016, 176, 17-30. [CrossRef]

80. Biudes, M.S.; Vourlitis, G.L.; Machado, N.G.; de Arruda, P.H.Z.; Neves, G.A.R.; de Almeida Lobo, F.; Neale, C.M.U.; Nogueira, J.S. Patterns of energy exchange for tropical ecosystems across a climategradient in Mato Grosso, Brazil. Agric. For. Meteorol. 2015, 202, 13. [CrossRef]

81. Liu, X.; Chen, X.; Li, R.; Long, F.; Zhang, L.; Zhang, Q.; Li, J. Water-use efficiency of an old-growth forest in lower subtropical China. Sci. Rep. 2017, 7, 42761. [CrossRef] [PubMed]

82. Lu, X.; Liu, Z.; An, S.; Miralles, D.G.; Maes, W.; Liu, Y.; Tang, J. Potential of solar-induced chlorophyll fluorescence to estimate transpiration in a temperate forest. Agric. For. Meteorol. 2018, 252, 75-87. [CrossRef]

83. Lewis, S.L.; Brando, P.M.; Phillips, O.L.; van der Heijden, G.M.; Nepstad, D. The 2010 Amazon drought. Science 2011, 331, 554. [CrossRef]

84. Phillips, O.L.; Aragão, L.E.O.C.; Lewis, S.L.; Fisher, J.B.; Lloyd, J.; López-González, G.; Malhi, Y.; Monteagudo, A.; Peacock, J.; Carlos, A.; et al. Quesada. Drought sensitivity of the Amazon rainforest. Science 2009, 323, 1344-1348. [CrossRef]

85. Pau, S.; Detto, M.; Kim, Y.; Still, C.J. Tropical forest temperature thresholds for gross primary productivity. Ecosphere 2018, 9, 1-13. [CrossRef]

86. Moreira de Araújo, F.; Ferreira, L.G.; Arantes, A.E. Distribution Patterns of Burned Areas in the Brazilian Biomes: An Analysis Based on Satellite Data for the 2002-2010 Period. Remote Sens. 2012, 4, 1929-1946. [CrossRef]

87. Laurance, W.F.; Useche, D.C.; Rendeiro, J.; Kalka, M.; Bradshaw, C.J.; Sloan, S.P.; Laurance, S.G.; Campbell, M.; Abernethy, K.; Alvarez, P.; et al. Averting biodiversity collapse in tropical forest protected areas. Nature 2012, 489, 290-294. [CrossRef] [PubMed]

88. Putz, S.; Groeneveld, J.; Henle, K.; Knogge, C.; Martensen, A.C.; Metz, M.; Metzger, J.P.; Ribeiro, M.C.; de Paula, M.D.; Huth, A. Long-term carbon loss in fragmented Neotropical forests. Nat. Commun. 2014, 5, 5037. [CrossRef] [PubMed]

89. Giulietti, A.M.; Harley, R.M.; De Queiroz, L.P.; Van Den Berg, C. Biodiversity and Conservation of Plants in Brazil. Conserv. Biol. 2005, 19, 632-640. [CrossRef]

90. Schwieder, M.; Leitão, P.J.; da Cunha Bustamante, M.M.; Ferreira, L.G.; Rabe, A.; Hostert, P. Mapping Brazilian savanna vegetation gradients with Landsat time series. Int. J. Appl. Earth Obs. Geoinf. 2016, 52, 361-370. [CrossRef] 
91. Abreu, R.C.R.; Hoffmann, W.A.; Vasconcelos, H.L.; Pilon, N.A.; Rossatto, D.R.; Durigan, G. The biodiversity cost of carbon sequestration in tropical savanna. Sci. Adv. 2017, 3, 7. [CrossRef] [PubMed]

92. Murphy, B.P.; Andersen, A.N.; Parr, C.L. The underestimated biodiversity of tropical grassy biomes. Philos. Trans. R. Soc. Lond. Ser. B Biol. Sci. 2016, 371. [CrossRef]

93. Parr, C.L.; Lehmann, C.E.; Bond, W.J.; Hoffmann, W.A.; Andersen, A.N. Tropical grassy biomes: Misunderstood, neglected, and under threat. Trends Ecol. Evol. 2014, 29, 205-213. [CrossRef]

94. John Grace, J.; San José, J.; Meir, P.; Miranda, H.S.; Montes, R.A. Productivity and carbon fluxes of tropicalsavannas. J. Biogeogr. 2006, 33, 14.

95. Ferreira, L.; Fernandez, L.; Sano, E.; Field, C.; Sousa, S.; Arantes, A.; Araújo, F. Biophysical Properties of Cultivated Pastures in the Brazilian Savanna Biome: An Analysis in the Spatial-Temporal Domains Based on Ground and Satellite Data. Remote Sens. 2013, 5, 307-326. [CrossRef]

96. Beuchle, R.; Grecchi, R.C.; Shimabukuro, Y.E.; Seliger, R.; Eva, H.D.; Sano, E.; Achard, F. Land cover changes in the Brazilian Cerrado and Caatinga biomes from 1990 to 2010 based on a systematic remote sensing sampling approach. Appl. Geogr. 2015, 58, 116-127. [CrossRef]

97. Alvarado, S.T.; Fornazari, T.; Cóstola, A.; Morellato, L.P.C.; Silva, T.S.F. Drivers of fire occurrence in a mountainous Brazilian cerrado savanna: Tracking long-term fire regimes using remote sensing. Ecol. Indic. 2017, 78, 270-281. [CrossRef]

98. Hoekstra, J.M.; Boucher, T.M.; Ricketts, T.H.; Roberts, C. Confronting a biome crisis: Global disparities of habitat loss and protection. Ecol. Lett. 2005, 8, 7. [CrossRef]

99. Zhang, Y.; Joiner, J.; Gentine, P.; Zhou, S. Reduced solar-induced chlorophyll fluorescence from GOME-2 during Amazon drought caused by dataset artifacts. Glob. Chang. Biol. 2018, 2229-2230. [CrossRef] [PubMed]

100. Köhler, P.; Guanter, L.; Kobayashi, H.; Walther, S.; Yang, W. Assessing the potential of sun-induced fluorescence and the canopy scattering coefficient to track large-scale vegetation dynamics in Amazon forests. Remote Sens. Environ. 2017, 769-785. [CrossRef]

101. SIF, STRESS, and GPP in Amazonia. Available online: https://ocov2.jpl.nasa.gov/files/ocov2/Baker2018Aug143.pdf (accessed on 23 July 2019).

102. Ministério do Meio Ambiente. Available online: http://www.mma.gov.br (accessed on 23 July 2019).

103. Nogueira, J.; Rambal, S.; Barbosa, J.; Mouillot, F. Spatial Pattern of the Seasonal Drought/Burned Area Relationship across Brazilian Biomes: Sensitivity to Drought Metrics and Global Remote-Sensing Fire Products. Climate 2017, 5, 42. [CrossRef]

104. Malhi, J.; Roberts, J.T.; Betts, R.A.; Killeen, T.J.; Li, W.; Nobre, C.A. Climate Change, Deforestation, and the Fate of the Amazon. Science 2008, 319, 169-174. [CrossRef]

105. Hilker, T.; Lyapustin, A.I.; Hall, F.G.; Myneni, R.; Knyazikhin, Y.; Wang, Y.; Sellers, P.J. On the measurability of change in Amazon vegetation from MODIS. Remote Sens. Environ. 2015, 166, 233-242. [CrossRef]

106. Grecchi, R.C.; Gwyn, Q.H.J.; Bénié, G.B.; Formaggio, A.R.; Fahl, F.C. Land use and land cover changes in the Brazilian Cerrado: A multidisciplinary approach to assess the impacts of agricultural expansion. Appl. Geogr. 2014, 55, 300-312. [CrossRef]

107. Reynolds, J.; Wesson, K.; Desbiez, A.; Ochoa-Quintero, J.; Leimgruber, P. Using Remote Sensing and Random Forest to Assess the Conservation Status of Critical Cerrado Habitats in Mato Grosso do Sul, Brazil. Land 2016, 5, 12. [CrossRef]

108. Arantes, A.E.; Ferreira, L.G.; Coe, M.T. The seasonal carbon and water balances of the Cerrado environment of Brazil: Past, present, and future influences of land cover and land use. ISPRS J. Photogramm. Remote Sens. 2016, 117, 66-78. [CrossRef]

109. Junk, W.J.; da Cunha, C.N.; Wantzen, K.M.; Petermann, P.; Strüssmann, C.; Marques, M.I.; Adis, J. Biodiversity and its conservation in the Pantanal of Mato Grosso, Brazil. Aquat. Sci. 2006, 68, 278-309. [CrossRef]

110. Assine, M.L.; Corradini, F.A.; Pupim, F.d.N.; McGlue, M.M. Channel arrangements and depositional styles in the São Lourenço fluvial megafan, Brazilian Pantanal wetland. Sediment. Geol. 2014, 301, 172-184. [CrossRef]

111. Costa, M.; Telmer, K.H.; Evans, T.L.; Almeida, T.I.R.; Diakun, M.T. The lakes of the Pantanal: Inventory, distribution, geochemistry, and surrounding landscape. Wetl. Ecol. Manag. 2015, 23, 19-39. [CrossRef]

112. Hellman, F. Modeling Land Use Change in the Pantanal; Wageningen University: Wageningen, The Netherlands, 2005. 
113. Furquim, S.A.C.; Graham, R.C.; Barbiero, L.; Queiroz Neto, J.P.; Vidal-Torrado, P. Soil mineral genesis and distribution in a saline lake landscape of the Pantanal Wetland, Brazil. Geoderma 2010, 154, 518-528. [CrossRef]

114. Paz, A.R.d.; Collischonn, W.; Tucci, C.E.M.; Padovani, C.R. Large-scale modelling of channel flow and floodplain inundation dynamics and its application to the Pantanal (Brazil). Hydrol. Process. 2011, 25, 1498-1516. [CrossRef]

115. Zani, H.; Assine, M.L.; McGlue, M.M. Remote sensing analysis of depositional landforms in alluvial settings: Method development and application to the Taquari megafan, Pantanal (Brazil). Geomorphology 2012, 161-162, 82-92. [CrossRef]

116. Silva, P.F.d.; Lima, J.R.d.S.; Antonino, A.C.D.; Souza, R.; Souza, E.S.d.; Silva, J.R.I.; Alves, E.M. Seasonal patterns of carbon dioxide, water and energy fluxes over the Caatinga and grassland in the semi-arid region of Brazil. J. Arid Environ. 2017, 147, 71-82. [CrossRef]

117. Ribeiro, E.M.S.; Arroyo-Rodríguez, V.; Santos, B.A.; Tabarelli, M.; Leal, I.R.; Barlow, J. Chronic anthropogenic disturbance drives the biological impoverishment of the Brazilian Caatinga vegetation. J. Appl. Ecol. 2015, 52, 611-620. [CrossRef]

118. de Oliveira, G.; Araújo, M.B.; Rangel, T.F.; Alagador, D.; Diniz-Filho, J.A.F. Conserving the Brazilian semiarid (Caatinga) biome under climate change. Biodivers. Conserv. 2012, 21, 2913-2917. [CrossRef]

119. Schulz, C.; Koch, R.; Cierjacks, A.; Kleinschmit, B. Land change and loss of landscape diversity at the Caatinga phytogeographical domain-Analysis of pattern-process relationships with MODIS land cover products (2001-2012). J. Arid Environ. 2017, 136, 54-74. [CrossRef]

120. Ribeiro, M.C.; Metzger, J.P.; Martensen, A.C.; Ponzoni, F.J.; Hirota, M.M. The Brazilian Atlantic Forest: How much is left, and how is the remaining forest distributed? Implications for conservation. Biol. Conserv. 2009, 142, 1141-1153. [CrossRef]

121. Tabarelli, M.; Mantovani, W.; Peres, C.A. Effects of habitat fragmentation on plant guild structure in the montane Atlantic forest of southeastern Brazil. Biol. Conserv. 1999, 91, 119-128. [CrossRef]

122. Dupas, C. SAR and LANDSAT TM image fusion for land cover classification in the Brazilian Atlantic Forest Domain. Int. Arch. Photogramm. Remote Sens. 2000, 33, 96-108.

123. Keuroghlian, A.; Eaton, D.P. Removal of palm fruits and ecosystem engineering in palm stands by white-lipped peccaries (Tayassu pecari) and other frugivores in an isolated Atlantic Forest fragment. Biodivers. Conserv. 2008, 18, 1733-1750. [CrossRef]

124. Roesch, L.F.; Vieira, F.; Pereira, V.; Schünemann, A.L.; Teixeira, I.; Senna, A.J.; Stefenon, V.M. The Brazilian Pampa: A Fragile Biome. Diversity 2009, 1, 182-198. [CrossRef]

125. Overbeck, G.; Muller, S.; Fidelis, A.; Pfadenhauer, J.; Pillar, V.; Blanco, C.; Boldrini, I.; Both, R.; Forneck, E. Brazil's neglected biome: The South Brazilian Campos. Perspect. Plant Ecol. Evol. Syst. 2007, 9, 101-116. [CrossRef]

126. Frankenberg, C. Solar Induced Chlorophyll Fluorescence OCO-2 Lite Files (B7000) User Guide; California Institute of Technology/Jet Propulsion Laboratory: Pasadena, CA, USA, 2015; pp. 1-10.

127. Eldering, A.; Basilio, R.; Schimel, D.; O’Dell, C. First results from Orbiting Carbon Observatory-2 (OCO-2) and prospects for OCO-3. In Proceedings of the EGU General Assembly Conference Abstracts, Vienna, Austria, 23-28 April 2017; p. 10215.

128. Joiner, J.; Guanter, L.; Lindstrot, R.; Voigt, M.; Vasilkov, A.P.; Middleton, E.M.; Huemmrich, K.F.; Yoshida, Y.; Frankenberg, C. Global monitoring of terrestrial chlorophyll fluorescence from moderate-spectral-resolution near-infrared satellite measurements: Methodology, simulations, and application to GOME-2. Atmos. Meas. Tech. 2013, 6, 2803-2823. [CrossRef]

129. Magney, T.S.; Frankenberg, C.; Fisher, J.B.; Sun, Y.; North, G.B.; Davis, T.S.; Kornfeld, A.; Siebke, K. Connecting active to passive fluorescence with photosynthesis: A method for evaluating remote sensing measurements of Chl fluorescence. New Phytol. 2017, 1594-1608. [CrossRef] [PubMed]

130. Osterman, G.; Eldering, A.; Avis, C.; Chafin, B.; O’Dell, C.; Frankenberg, C.; Fisher, B.; Mandrake, L.; Wunch, D.; Granat, R.; et al. Orbiting Carbon Observatory-2 (OCO-2) Data Product User's Guide, Operational L1 and L2 Data Versions 8 and 8R; National Aeronautics and Space Administration, Jet Propulsion Laboratory, California Institute of Technology: Pasadena, CA, USA, 2017; pp. 1-73.

131. Köhler, P.; Guanter, L.; Frankenberg, C. Simplified Physically Based Retrieval of Sun-Induced Chlorophyll Fluorescence From GOSAT. IEEE Geosci. Remote Sens. Lett. 2015, 12, 1446-1450. [CrossRef] 
132. Yoshida, Y.; Joiner, J.; Tucker, C.; Berry, J.; Lee, J.E.; Walker, G.; Reichle, R.; Koster, R.; Lyapustin, A.; Wang, Y. The 2010 Russian drought impact on satellite measurements of solar-induced chlorophyll fluorescence: Insights from modeling and comparisons with parameters derived from satellite reflectances. Remote Sens. Environ. 2015, 166, 163-177. [CrossRef]

133. Wickham, H.; François, R.; Henry, L.; Müller, K. dplyr: A Grammar of Data Manipulation; RStudio: Boston, MA, USA, 2018.

134. Wickham, H. tidyverse: Easily Install and Load the 'Tidyverse'; RStudio: Boston, MA, USA, 2017.

135. Wickham, H. ggplot2: Elegant Graphics for Data Analysis; Springer: New York, NY, USA, 2016.

136. R Development Core Team R: A Language and Environment for Statistical Computing; R Foundation for Statistical Computing: Vienna, Austria, 2010.

137. Zeileis, A.; Grothendieck, G. zoo: S3 Infrastructure for Regular and Irregular Time Series. J. Stat. Softw. 2005, 14, 17. [CrossRef]

138. Jönsson, P.; Eklundh, L. TIMESAT-A program for analyzing time-series of satellite sensor data. Comput. Geosci. 2004, 30, 833-845. [CrossRef]

139. Eklundh, L.; Jönsson, P. TIMESAT 3.3 Software Manual; Lund University: Lund, Sweden, 2017; pp. 1-92.

140. Pau, S.; Still, C.J. Phenology and productivity of C3 and C4 grasslands in Hawaii. PLoS ONE 2014, 9, e107396. [CrossRef] [PubMed]

141. Muylaert, R.L.; Vancine, M.H.; Rodrigo Bernardo, R.; Oshima, J.E.M.; Sobral-Souza, T.; Tonetti, V.R.; Niebuhr, B.B.; Ribeiro, M.C. Uma Nota Sobre os Limites Territoriais da Mata AtláNtica. Oecologia Aust. 2018, 22, 302-312. [CrossRef]

142. Tabarelli, M.; Aguiar, A.V.; Ribeiro, M.C.; Metzger, J.P.; Peres, C.A. Prospects for biodiversity conservation in the Atlantic Forest: Lessons from aging human-modified landscapes. Biol. Conserv. 2010, 143, 2328-2340. [CrossRef]

143. Bergier, I. Effects of highland land-use over lowlands of the Brazilian Pantanal. Sci. Total Environ. 2013, 463-464, 1060-1066. [CrossRef] [PubMed]

144. Ehleringer, J.R. Implications of Quantum Yield Differences on the Distributions of C 3 and C 4 Grasses. Oecologia 1978, 31, 13. [CrossRef] [PubMed]

145. Ehleringer, J.R.; Bjorkman, O. Quantum Yields for CO2 Uptake in C3 and C4 Plants. Plant Physiol. 1977, $59,5$. [CrossRef]

146. Still, C.J.; Pau, S.; Edwards, E.J. Land surface skin temperature captures thermal environmentsof C3 and C4 grasses. Glob. Ecol. Biogeogr. 2014, 23, 11. [CrossRef]

147. Monteith, J.L. Climate and the efficiency of crop production in Britain. Phil. Trans. R. Soc. Land. 1977, 281, 277-294. [CrossRef]

148. Monteith, J.L. Solar Radiation and Productivity in Tropical Ecosystems. J. Appl. Ecol. 1972, 9, 747-766. [CrossRef]

149. Pau, S.; Edwards, E.J.; Still, C.J. Improving our understanding of environmental controls on the distribution of C3 and C4 grasses. Glob. Chang. Biol. 2013, 19, 184-196. [CrossRef] [PubMed]

150. Damm, A.; Paul-Limoges, E.; Haghighi, E.; Simmer, C.; Morsdorf, F.; Schneider, F.D.; van der Tol, C.; Migliavacca, M.; Rascher, U. Remote sensing of plant-water relations: An overview and future perspectives. J. Plant Physiol. 2018, 227, 3-19. [CrossRef] [PubMed]

151. Karnieli, A.; Agam, N.; Pinker, R.T.; Anderson, M.; Imhoff, M.L.; Gutman, G.G.; Panov, N.; Goldberg, A. Use of NDVI and Land Surface Temperature for Drought Assessment: Merits and Limitations. J. Clim. 2010, 23, 618-633. [CrossRef]

152. Jin, M.; Dickinson, R.E. Land surface skin temperature climatology: Benefitting from the strengths of satellite observations. Environ. Res. Lett. 2010, 5, 044004. [CrossRef]

153. Kim, Y.; Still, C.J.; Hanson, C.V.; Kwon, H.; Greer, B.T.; Law, B.E. Canopy skin temperature variations in relation to climate, soil temperature, and carbon flux at a ponderosa pine forest in central Oregon. Agric. For. Meteorol. 2016, 226-227, 161-173. [CrossRef]

(C) 2019 by the authors. Licensee MDPI, Basel, Switzerland. This article is an open access article distributed under the terms and conditions of the Creative Commons Attribution (CC BY) license (http://creativecommons.org/licenses/by/4.0/). 